\title{
Suriyelilerin Sinır Kentlerdeki Toplumsal Kabul ve Uyum Sürecine İlişkin Bir Araştırma
}

\author{
DOI: 10.26466/opus. 899920 \\ * \\ İpek Agcada ̆ Celik* \\ * Dr. Öğr. Üyesi, Kilis 7 Aralık Üniversitesi, Fen-Edebiyat Fakültesi, Kilis/Türkiye \\ E-Posta: ipekagcadag@kilis.edu.tr \\ ORCID: $0000-0002-2409-668 \mathrm{X}$
}

\section{Öz}

Bu çalışma, 2011 yılında Suriye savaşına bağh zorunlu göç hareketi sonrasında Türkiye'ye yerleşen Suriyeli kitlenin toplumsal kabul ve uyum sürecini Kilis, Gaziantep ve Hatay örneği üzerinden açıklamaktadır. Kitlesel zorunlu göç hareketinin üzerinden geçen yıllar beraberinde Suriyelilerin ülkemize toplumsal kabul ve uyum sürecini gündeme getirmektedir. Sadece temel insani ihtiyaçların karşılanmasının ötesinde, göç eden kitlenin kendi kültürel değerlerini kaybetmeden, ev sahibi toplumun birtakım sosyo-kültürel değerlerini özümseyerek birlikte huzur ve barış içerisinde yaşamalarıyla, toplumsal kabul ve uyum sürecinin ilerlemesinden bahsedilebilmektedir. Ülkemizdeki Suriyeli kitleyle yoğun bir etkileşim içerisinde olan sınır kentlerin (Kilis, Gaziantep ve Hatay) yerel halkının toplumsal kabul ve uyum sürecine ilişkin fikir, alga ve tutumları bu nedenle oldukça önemli görünmektedir. Bu noktadan hareketle, nicel araştırma deseninde tasarlanan çalışmada söz konusu bu üç sınır kentin yerel halkına, toplumsal kabul ve uyuma ilişkin önemli göstergelerin (iletişim, barınma, istihdam, eğitim, evlilik, arkadaşlık, komşuluk, ticaret vd.) gerçekleşme düzeyleriyle ilgili sorular yöneltilmiş̧ir. Böylece araştırma sonucunda, Suriyeli kitlenin demografik olarak yükünü önemli ölçüde üstlenen sınır kentlerin yerel halkının, Suriyelilerle birlikte yaşama deneyimleri hakkında birçok bulguya ulaşılmıştır. Araştırma bulgularından yola çıkarak Suriyeliler ve sınır kentler halkının sadece yoğun bir etkileşim değil, ayn zamanda bir iletişim ve kaynaşma içerisinde olduğu, toplumsal kabul ve uyum anlamında kat edilmesi gereken bir yol olmakla birlikte, bu yolun sanılandan daha kısa olduğu sonucuna ulaşılmaktadır.

Anahtar Kelimeler: Zorunlu göç, Suriyeliler, sinır kentler, toplumsal kabul, uyum. 


\title{
A Study on the Social Acceptance and Cohesion Processes of Syrians in Border Cities
}

\begin{abstract}
This study explains the social acceptance and cohesion processes of the Syrian population that were involuntarily migrated to, and settled in, Turkey after the Syrian war in 2011 through the examples of Kilis, Gaziantep, and Hatay. The years that have passed since the mass involuntary migration movement have brought forward the social acceptance and cohesion processes of Syrians to our country. Beyond meeting basic humanitarian needs, the progress of social acceptance and cohesion processes can only be spoken of by migrants living together in peace and harmony by absorbing certain socio-cultural values of the host society without losing their own cultural values. For this reason, the opinions, perceptions, and attitudes of the local people of the border cities (Kilis, Gaziantep, and Hatay), which are in an intense interaction with the Syrian population in our country, regarding the social acceptance and cohesion processes seem very important. From this point of view, in this study, which was designed in a quantitative research design, questions were asked to the local people of these three border cities about the realization levels of important indicators (communication, accommodation, employment, education, marriage, friendship, neighborhood, trade etc.) regarding social recognition and adaptation. Thus, as a result of the study, many findings were obtained about the experiences of the local people of the border cities living with Syrians who undertake a significant demographic burden of the Syrian population. Based on the findings of the study, it is concluded that the Syrians and the people of the border cities are not only in an intense interaction, but also in communication and cohesion, and although there is a journey to undertake in terms of social acceptance and cohesion, this journey is shorter than expected.
\end{abstract}

Keywords: Involuntary migration, Syrians, border cities, social acceptance, cohesion 


\section{Giriş}

Gözlerini dünyaya açtıkları yerleşim yerinde tüm yaşamını geçirip dünyaya gözlerini burada kapayan insanların sayısı dünya çapında azalma göstermektedir. Bu durumun temel sebebi ise, çok çeşitli sebeplerle insanların fiziki olarak yer değiştirmesi başka bir deyişle doğduğu yerden farklı bir köyde, kentte, ülkede hatta kıtada yaşamını sürdürme kararıdır. Bu karar, üzerinde düşünülmüş ve daha iyi yaşam şartlarına kavuşulacağı umuduyla verilmiş olabileceği gibi, yaşadığı yerden farklı bir yerde yaşama arzusu hiç olmamasına rağmen savaş, kıtlık, iklim değişikliği gibi sorunların sebep olduğu çaresizlik nedeniyle zorunlu olarak verilmiş de olabilir. Sebebi her ne olursa olsun göç deneyimi, göç eden kişilerin yaşamını ekonomik, sosyal, kültürel, psikolojik ve bazen hukuki yönden değişikliğe uğratmaktadır. Elbette zorunlu göç deneyiminin kişiler üzerinde gönüllü göç deneyimine göre daha sarsıcı etkileri olabilmektedir. Zorunlu göçe maruz kalan kişilerin kitlesel olarak anavatanlarından farklı bir yerleşim yerinde yeni bir düzen kurma deneyimi ise, sadece göç edenleri değil aynı zamanda onları karşılayan ev sahibi toplumu da etkilemektedir. Uluslararası göç literatürü incelendiğinde ise, bu etkinin yönünün genellikle hem göçmenler hem de ev sahibi toplumlar için negatif olduğu görülmektedir. Zorunlu göç gerçekleştiren kişilerin yerleştikleri yeni topraklarda güvenlik, barınma, istihdam, eğitim, sağlık gibi temel ihtiyaçlarının bir şekilde karşılandığ 1 görülmekle birlikte, bu toprakların yerlileriyle birlikte yeni bir yaşam kurma, kendilerini yerlilere bir nevi kabul ettirme süreci tahmin edilenden daha uzun bir zaman diliminde gerçekleşmektedir. Ev sahibi toplum üyeleri açısından ise kendi topraklarında dil, ırk, din, etnik köken, mezhep, kültür ve yaşam tarzı gibi unsurlardan birkaçı veya tümü farklı olan göçmenlerle bir anda birlikte yaşamak zorunda kalmak oldukça farklı ve tedirgin edici olabilmektedir. Bu durum her iki tarafı rahatsız edici bir sürece sevk etmektedir. Toplumsal kabul ve uyum adı verilen bu sürecin nasıl ilerleyeceği ve ne kadar uzun süreceği ise her göç deneyiminde bireysel ve toplumsal boyutta farklllık göstermektedir. Göç eden ve göç alan toplumlar arasında yukarıda sıralanan ırk, din, dil, etnik köken, mezhep, kültür ve yaşam tarzı gibi unsurlardan çoğunun farklı olduğu durumlarda toplumsal kabul ve uyum sürecinin daha uz- 
un sürmesi kaçınılmaz olmaktadır. Farklılıklar çoğaldıkça göç edenlerin uyum süreci, yerel halkın ise toplumsal kabul süreci zorlaşacak ve zamana yayılacaktır. Bu sürecin uzaması ve daha sancılı bir hâl alması ise taraflar arasında sosyal, kültürel, ekonomik ve psikolojik boyutlarda gerginliklerin yaşanmasına ve huzur ortamının bozulmasına neden olacaktır. Bu noktada, ülkelerin göç yönetimleri ve krizi atlatma becerileri/politikaları büyük önem taşımaktadır. Siyasi yönetimler her iki tarafın toplumsal kabul ve uyum sürecini yumuşatacak politikalar geliştirmek ve uygulamakla yükümlü olacaklardır. Geliştirilen plan, program ve uygulamalarla bu süreci hafifleterek ev sahibi toplum ve göçmenler lehine çevirebileceklerdir. Böylece toplumsal kabul ve uyum sürecinin tarafları karşılıklı bir hoşgörü içerisinde aynı topraklar üzerinde birbirlerinin farklılıklarına saygı duyarak yaşamlarını birlikte sürdürebileceklerdir.

Göç ve sonrasında yaşanan toplumsal kabul sürecinin bir örneğine son yıllarda Türkiye şahit olmaktadır. Dünyanın son yıllarda yaşadığı en büyük insanlık krizi olan Suriye savaşına bağlı kitlesel zorunlu göç hareketi 2011 yılından beri dünya gündeminde olmakla birlikte, Türkiye ve Suriye'nin bulunduğu bölge ülkelerinin aşmakla uğraştı̆̆1 en önemli sorunların başında gelmektedir. Konuya Türkiye özelinde yaklaşıldığında, ülkenin kriz yönetimi sayesinde geçici koruma statüsü kapsamına alınan, güvenlikleri sağlanan ve temel ihtiyaçları hızlı bir şekilde giderilen Suriyelilerin gönüllü geri dönüşlerinin gerçekleşmemesi yeni konuları ülke gündemine taşımaktadır. Türkiye ve özellikle Suriyeli kitlenin demografik olarak yükünü üstlenen sınır kentlerin gündemini toplumsal kabul ve uyum süreci meşgul etmektedir. Sadece temel insani ihtiyaçların karşılanmasının ötesinde, göç eden kitlenin kendi kültürel değerlerini kaybetmeden, ev sahibi toplumun birtakım sosyo-kültürel değerlerini özümsemenin gerçeklemesiyle toplumsal kabul ve uyum sürecinin ilerlemesinden bahsedilebilmektedir. Bu nedenle, konuyla ilgili mevcut durumu tespit etmek hem günümüzde gelinen noktayı ortaya çıkaracak hem de gelecek için hazırlanacak program ve politikalara 1şık tutacaktır. Yoğun etkileşimin, sağlıklı bir iletişim ve sosyo-kültürel uyum gerçekleşmediğinde, toplumsal kabul konusunda bir avantaj olmaktan öte bir dezavantaja dönüştüğü göz önünde bulundurulduğunda, yerel halkla yapılan saha çalışmalarının önemi daha fazla anlaşılmaktadır. Bu 
noktadan hareketle, bu araştırma Suriyeli kitleyle gündelik yaşamda yoğun bir etkileşim içerisinde olan Türkiye'nin sınır kentleri Kilis, Gaziantep ve Hatay yerli halkının toplumsal kabul ve uyum sürecine ilişkin bulgulara ulaşmayı amaçlamaktadır.

\section{Toplumsal Kabul ve Uyum}

Sosyal bilimler alanında göçün önemli bir alt başlık olarak oldukça kapsayıcı bir yerde durması, göç süreçlerinin sosyo-politik anlamdaki merkeziliği ile yakından ilişkilidir. Özellikle mekân ve toplum ilişkilerinin ürettiği bir kategori olarak kimliğin oluşumu konusu, postmodern dönemin önemli tartışma başlıklarından biri haline gelmiştir. Bu bağlamda mekânsal yitimlerin "sürekli kimlik algısı" üzerindeki etkileri konusu, göç-mekân-mekânsızlık etkileşimi bağlamında önem kazanmaktadır. Nitekim göç meselesi, birçok ülkede etki ve sonuçları bakımından ilk etapta genellikle negatif yaklaşımlarla beslenmekte, ayrıca toplumsal temkin ve teyakkuzların da eşlik ettiği bir psikolojiyle ilerlemektedir. Dolayısıyla yerli halkın ekonomik kaygıları, kamu hizmetlerinin tedariki hususunda öne çıkan endişeler, bazen göçmen sayısının fazlalığı gibi etkenlerle bütünleşerek hem göçmenler hem de onları karşılayanlar açısından toplumsal kabul ve uyum sürecini zorlaştırmaktadır (Çakmak, 2018, s.354). Bu anlamda göçlerin, ev sahibi toplumların demografik yapısına, kentsel yerleşim düzenine, kamu hizmetlerine, emek piyasası şartlarına ve istihdam imkânlarına etkide bulunduğu, diğer yandan yeni gruplarla karşılaşmaya, görüş, düşünce ve davranışlarda değişikliğe neden oluşturması yönüyle de sosyal, ekonomik, hatta kültürel bakımlardan da önemli sonuçlar doğurmakta olduğu görülmektedir (Murat, 2007, s.94). Farklı yaşantılara ve farklı dini, sosyal ve kültürel değerlere sahip kişilerin bir arada yaşamaya başlamaları zorlukları da beraberinde getirmekte, bu anlamda, etkileşim her iki taraf için de değişimi zorunlu kılmaktadır (Yardım, 2017, s.177).

Toplumsal kabul ve uyum kavramlarının özelikle son dönemde uluslararası arenada yaşanan hızlı değişim ve dönüşümlerin bir sonucu olarak; sosyolojik bağlamda "göç" kavramı ile birlikte tartışılmasının hız kazandığ1 görülmektedir. Gerek göç kavramına ilişkin oluşturulan bu türden bir kavramsal sınıflandırma gerekse iç ve dış göç olarak yapılan 
genel sınıflama biçimi dikkate alındığında; göçün gerekçesi, göçün farklı alanlardaki bütünleşik etkileri, göçmen davranış ve tutumları, göç edilen bölgedeki yerleşik kesimin göçmenlere karşı tepkileri vb. hususlar her ne olursa olsun toplumsal kabul ve uyum konusu tüm bireyleri kapsamaktadır (Sözer, 2019, s.423). Göç eden kişiler ve göç edilen ülke vatandaşları arasındaki etkileşim, çoğunlukla göçmenlerin kendi kültürlerini gittikleri yeni ülkeye taşımaları nedeniyle kültürel değişim sürecini de beraberinde getirmektedir. Zira göç eylemiyle birlikte farklı kültürlerin karşılaşması söz konusu olmakta ve bu sayede insanların bir arada hayatlarını sürdürme isteği uyum sağlama süreciyle bir arada gerçekleşmektedir. Ancak kimi zaman bu süreç uyumsuzluk ve çatışma boyutuna varabilmekte, kültürler arasında iletişim kopuklukları ortaya çıkabilmektedir. Bu çerçevede, son birkaç yıldır bir arada yaşadığımız Suriyelilerin, Türk toplumuna uyum sağlayabilmesi ve Türk toplumunca da toplumsal kabul görüp görmeyeceği giderek toplumsal, siyasal ve ekonomik boyutları olan bir nitelik kazanmaya başlamıştır (Süleymanov, 2017, s.27).

Uyum, göçmenlerin kendi kültürel kimliğinden vazgeçmeden ev sahibi topluluğa uyumunu ve ev sahibi toplumun da kurumları ile birlikte mültecileri kabul ederek ihtiyaçlarını karşılaması biçiminde iki taraflı bir durumdur. Karşılıklı taraflar "uyum" ve "hoş karşılama" yaklaşımı içinde bulunduklarında olumlu bir durum ortaya çımaktadır. Göç ve uyum da bu bağlamda göçmenlerin geldikleri yeni topluma alışmaları ve ayrımcılık yaşamamaları konularını içermektedir. Bu noktada "en az yerleşikler kadar o toplum üyesi olma" uyum sürecinin nihai hedefi olarak ifade edilebilir. Uyum süreci göç nedenleri ile doğrudan bağlantılıdır. Ülkedeki emek gücü açığını kapatması için davet edilen göçmenlerle, savaştan canını kurtarıp ülkeye sığınan göçmenlerin uyumu aynı veriler/kavramlar üzerinden analiz edilemeyeceği gibi uyum süreçleri de aynı araçlarla yönetilememektedir (Canbey-Özgüler, 2018, s.1-2). Ayrıca, bu uyum yönetilmesi mümkün bir nüfus büyüklüğü ile sağlanabilmektedir. Ev sahibi toplum içerisindeki göçmen grupların nüfusları, uyum ve toplumsal kabul sürecinde önemli bir noktadır. Ev sahibi toplumda göçmen nüfus oranının artışı yerel halkta endişeye sebep olmakta, ayrıca oran yükseldikçe Türkiye ve özellikle Kilis örneğinde olduğu gibi uyumun çift taraflı olması gerektiği de herkese 
apaçlk gözükmektedir. Göçmenlerin resmi kabulünden önce onların ev sahibi topluma uyum sürecine yönelik hazırlıklar ve planlamalar yapılması, sürecin yönetimi açısından kolaylaştırıcı olabilir. Ancak, Türkiye örneğinde olduğu gibi beklenmedik şekilde ve sayıca yönetilmesi güç bir kitleyle karşılaşma, önceden planlanamayacak bir durumdur. Yine de toplumsal uyum tartışmalarını daha fazla gecikmeden ele almak önemlidir (Çakırer-Özservet, 2019, s.57-58).

Göçün, temelde bir yerinden olma/edilme ile başlayan fiziksel yönü ile birlikte yerleşik kodların esastan sarsılmasına yol açan tüm psikolojik eşikleri birlikte değerlendirildiğinde, her göç deneyiminin yeni bir yaşam pratiği inşa etme konusunda oldukça sancılı bir sürece karşılık geldiği ifade edilebilir. Özellikle yaşanılan yere ait koşulların bütünüyle sarsıldığı, gündelik hayat pratiklerine ilişkin rutinlerin bozulduğu ve göçün zorunlu bir seçenek haline geldiği zorunlu göçmenlik deneyiminde zaman/mekân tasavvurunun kalıcı olarak altüst olması kişiler açısından daha yıkıcı ve onarımı zor bir yerinden edilme tecrübesi üretmektedir (Çakmak, 2018, s.354). Uyum süreci göçmen kitlelerin aşmak durumunda olduğu ve çözüme ulaştırmaları gereken sorunlar bütününün en başında gelmektedir. Yabancısı olduğu toplumun bir parçası haline gelerek, bütünleşerek yeniden bir toplumsallaşma sürecine dâhil olduğu bir süreçten söz edilmektedir. Bu bağlamda yeniden oluşturulan toplumsal inşa sürecinde gerek göçmenler gerekse de bölge halkı arasında toplumsallığın inşası sırasında toplumsallaşma araçlarının birbiri ile uyum içinde olması uyum sürecinin pozitif yönde ilerlemesi adına önem arz etmektedir (Adıgüzel, 2020). Uyum süreci göçmenin köken ülkedeki konumu, göç ettiği ülkedeki konumu ve bu konumları belirleyen değişkenlerin etkisi altındadır. Göçmenin, eğitim durumu, mesleği ve statü farklılıkları sürecin yapısında farklı seçeneklerin ortaya çıkmasını sağlamaktadır (Güven, 1996, s.42-44). Ayrıca uyum süreci üzerinde ekonomik durum, kültürel yakınlık, dil, din gibi faktörlerin etkilerinin yanı sıra, uyum sorunlarının kısa veya uzun vadede çözümünü göç eden bireyler ile yerli halk arasındaki ilişkiler oluşturmaktadır ki bu da büyük ölçüde tarafların kültür ve ekonomik düzeyleri ile yakından ilişkilidir. Göçmenlerin göç ettikleri yerleşim yerinde özellikle, biyolojik (akrabalık) ve sosyal (kabile, aşiret, vb.) bağlarının olması mekânın benimsenmesi ve yerli halkla ilişki ku- 
rulmasında önemli bir rol oynamaktadır (Apak, 2014, s.58-59). Göç eden insanlar ile göç ettikleri ülkenin etnik kökeni, dini inanc1, kültürel bağ1 ve benzerlikleri ne kadar çok ise, bu insanların ülkeye uyumunun da o kadar kolay olması ve o kadar az sorun yaşanması beklenmektedir. Örneğin Türkiye yıllarca Bulgaristan'dan gelen Türk kökenli mültecileri kabul etme ve onlara kolaylık sağlama politikasını takip etmiştir (Türkoğlu, 2011, s.109).

Göçmenler açısından ev sahibi toplumla birlikte barınma, sağlık, istihdam, eğitim gibi alanlarda bir bütünleşme sağlanamadıkça; içe kapanma, kendi sahip olduklarını daha şiddetle savunur hale gelme, "öteki" ne karşı sürekli tetikte olma, önyarg1 ve kalıp yargılar oluşturma gibi olumsuz sonuçlar ortaya çıkarabilmektedir. Bu bağlamda toplumsal bütünleşmenin kaynağının sadece "yeni gelenler" değil, aynı zamanda "ev sahibi" olduğu unutulmamalıdır (Sözer, 2019, s.423). Bu sürecin seyrini göçmenlerin sosyolojik nitelikleri kadar yerel halkın sosyolojik nitelikleri, göçmenlerle ilgili yaşantı, algı ve beklentileri de belirlemektedir. Nitekim göçmenlerin ev sahibi topluma sosyo-kültürel olarak uyum sağlaması kendilerinin çabası ve davranışları kadar, aynı zamanda göç ettiği toplumdaki kişilerin de göçmenlerle ilgili tutum ve davranışları da etkili olmaktadır (Deniz, 2009, s.189). Göçmenler ve ev sahibi toplumlar arasında toplumsal temasın azlığı önyargıyı besleyerek, ayrışma ve toplumsal uzaklığın (sosyal mesafenin) artmasına neden olmakta, toplumsal kabul yerine toplumsal mesafe koymak da ayrımcılığa ve şiddete giden süreci başlatmaktadır (Çuhadar-Gürkaynak, 2012, s.3). Birey ve sosyal grupların fiziki olarak aynı mekânda birlikte yaşamalarına rağmen birbirleriyle sosyal olarak kurdukları ilişkilerin zayıf ve sınırlı kalması durumunu tanımlamak için kullanılan toplumsal uzaklık (sosyal mesafe) kavramı sosyal psikolojide; rrk, din, milliyet gibi farklı sosyal grup üyelerinin birbirlerini kabul etme ya da reddetme derecesi olarak izah edilmektedir (Budak, 2000, s.690). Toplumsal etkileşimin ve temasın olmaması ya da azalması ise, yaşam alanlarının homojenleşmesine ve bireyleri "öteki" gruba karşı ayrımcılık yapmaya hazır hale getirmektedir (Çuhadar-Gürkaynak, 2012, s.3). Ayrıca, göçmenlerin göç ettikleri ülkede nüfusu arttırmalarıyla birlikte, yerli halkın zihninde, göçmenlerin sosyal güvenlik hizmetlerine yük getireceklerine, kamu hizmetlerini aksatacaklarına, iş kaybına ve dolayısıyla gelir kaybına neden olacaklarına, suç 
olaylarının artacağına ve bulaşıcı hastalıkların görülme oranının yükseleceğine dair birtakım düşünceler hâkim olabilmektedir. Böylece göçmenlerin toplumsal uyumu, toplumsal kabul dâhilinde güçleşebilmektedir (Tunç, 2015, s.43). Bu olumsuz durumların yaşanmaması, yerel halk ve göç eden kişiler arasında toplumsal uzaklığın azalması ve bir arada huzur içerisinde yaşanabilmesi için toplumsal kabul ve uyum süreci oldukça büyük önem taşımaktadır.

Göç eden kişiler ve göç edilen ülke vatandaşları arasındaki etkileşim, çoğunlukla göçmenlerin kendi kültürlerini beraberinde gittikleri o ülkeye götürmelerinden kaynaklı kültürel değişim sürecini de beraberinde getirmektedir (Akıncı vd., 2015, s.69). Gerek göç eden kişiler, gerekse göç alan ülkeler açısından "uyum" kavramının öne çıkan en önemli boyutu sosyo-kültürel açıdan ortaya çıkmaktadır. Bu süreçte göçmenler açısından kendi üzerlerine düşen görev, yaşadıkları topluma ve o kültüre kendi öz kültürlerinden kopmadan uyum sağlayabilmek iken, göç edilen ülkeye ve ev sahibi topluma düşen görev ise, uyumun sağliklı gerçekleştirilebilmesi için doğru altyapının hazırlanması gerektiğidir. Toplumsal kabul ve uyum, bir süreci işaret etmektedir ve sadece tek bir grubun sorumluluğunda değildir. Hem göçmenlerin kendisi hem de ev sahibi devlet, kurumlar ve toplum uyumdan sorumlu olmaktadır (Yavuz, 2013, s. 615-616).

Ülkemizdeki Suriyeli nüfusun yoğunluğu beraberinde farklılıkları da getirmekte, bu farklılıkların yerel halkta meydana getirdiği algının önemi ise, yaşanan bu gerçeği bilimsel olarak araştırma zorunluluğunu ortaya çıkarmaktadır. Bu anlamda bu çalışmada, göçün yerel halktaki algisı ve toplumsal olarak kabul edilirliğinin yönü (Aktaş ve Gülçür, 2017, s. 241) bir saha araştırmasıyla ortaya çıkarılmaya çalışılmıştır.

\section{Metodoloji}

Göç sonrası toplumsal kabul ve uyum sürecinin çift taraflı olması ve bu sürecin aktörlerinin hem göçmenler hem de yerel halk olması, Suriye savaşına bağlı kitlesel göç hareketi sonrasında yerel halkın Suriyelilerle ilgili düşünce, tutum ve görüşlerini oldukça önemli bir hale getirmektedir. Suriye savaşı sonrası Türkiye'ye göç eden Suriyeli kitlenin ülkemizin dört bir yanına dağılmakla birlikte, anavatanlarına fiziki yakınlığı, sınır 
kapılarının varlığı, geçici barınma merkezlerinin bu şehirlerde kurulması gibi nedenlerden dolayı demografik olarak Türkiye'nin sınır kentlerinde yoğunlaştıkları görülmektedir. Suriyeli nüfusun Kilis, Gaziantep ve Hatay sınır kentlerinde yoğunlaşması, söz konusu kitleyle, yerel halkın gündelik yaşamda oldukça fazla bir etkileşime girmesine sebep olmaktadır. Bu nedenle, zorunlu göç hareketinin üzerinden geçen on yıllık süreçte kalıcllık eğilimi artan geçici koruma altındaki Suriyelilerin ülkemizdeki toplumsal kabul ve uyum süreçleri hakkında yapılacak bir araştırmanın, sınır kentler Gaziantep, Kilis ve Hatay'da yapılması ve bu şehirlerin yerli halkının konuyla ilgili görüşlerinin alınması önemli görülmektedir. Göç İdaresi Genel Müdürlüğü verilerine (10.03.2021) göre, Türkiye'deki geçici koruma kapsamında bulunan Suriyelilerin nüfusa oranla en yoğun oldukları ilk on il sıralaması şu şekildedir; Kilis $(\% 74,62)$, Hatay $(\% 26,36)$, Gaziantep $(\% 22,29)$, Şanlıurfa $(\% 21,57)$, Mersin $(\% 12,27)$, Adana $(\% 11,31)$, Mardin $(\% 10,46)$, Osmaniye $(\% 8,64)$, Kahramanmaraş $(\% 8,02)$, Bursa $(\% 5,85)$, Kayseri $(\% 5,67)$ ve Konya $(\% 5,33)$ dır. Türkiye' de bulunan toplam 3.604.049 Suriyelinin yaklaşık bir milyonuna (991.754 kişi) ülkemizin sadece 3 sınır kenti ev sahipliği yapmaktadır. Nüfusu 141.454 kişi olan Kilis'te 105.560 Suriyeli, nüfusu 1.654.907 kişi olan Hatay'da 436.274 Suriyeli ve nüfusu 2.085.795 kişi olan Gaziantep'te 449.920 Suriyeli yaşamını sürdürmekte, bu demografik baskının bu şehirlerde yaşayan yerel halkın Suriyelilerle ilgili görüş, algı ve tutumlarına etkisinin kaçınılmaz olduğu düşünülmektedir. Eğitim, istihdam, komşuluk, dostluk, evlilik gibi pek çok konuyu içeren toplumsal kabul ve uyum süreciyle ilgili görüşlerini, algılarını ve tutumlarını öğrenmek için yerli halka ulaşmak gerekmektedir. Özellikle cinsiyet, yaş, medeni durum ve eğitim düzeyi gibi demografik özellikleri farklı çok sayıda kişiye ulaşmanın, konuyla ilgili verilerin güvenirliğini artıracağ1 düşünülmektedir. Bu nedenle nicel araştırma deseniyle hazırlanan araştırma, Suriyeli nüfusun en yoğun olduğu sınır kentler Kilis, Hatay ve Gaziantep'te gerçekleştirilmiştir.

Görgül nitelikli ve tümdengelim yaklaşımını benimseyen nicel araştırmalar, gözlem ve ölçümlerin tekrarlanabildiği ve nesnelliğin ön plana çıktığ 1 araştırmalardır. Bu tür araştırmalarda, olguya ilişkin ne kadar, ne ölçüde, ne sıklıkla gibi sorulara yanıt aranmaktadır. Nicel araştırmalarda genellikle sayısal veriler toplanmakta, istatistiksel ve ma- 
tematiksel yöntemler kullanılarak analiz gerçekleştirilmekte ve sonuçlara ulaşılmaktadır. Araştırmacının amacının, betimlemeler, genellemeler yapmak ve geleceğe ilişkin kestirimlerde bulunmaksa nicel araştırmalar uygundur. Nicel araştırmalarda başlıca veri toplama tekniği anket olup bu araştırma türünde genelleme yapabilmek için geniş örneklem ve oldukça yapılandırılmış veri toplama araçları kullanılmaktadır (Gürbüz ve Şahin, 2018, s. 106). Veri toplama tekniği olarak anketin kullanıldığ 1 bu araştırmada, demografik sorulardan ve Suriyelilerin toplumsal kabul ve uyum sürecine ilişkin kapalı uçlu soruların yer aldığı iki bölümden oluşan yapılandırılmış bir görüşme formu kullanılmıştır. Kilis 7 Aralık Üniversitesi Etik Kurulu'nun 07.01.2021 tarihli ve 2021/01 toplantı sayılı etik kurul izni ile gerçekleştirilen bu araştırmada veriler Şubat 2021 tarihinde toplanmıştır. Katılımın gönüllülük esasına dayalı olduğu bu araştırmada, Covid-19 pandemisi nedeniyle, katılımcıların bir kısmının yüz yüze, bir kısmının da bilgisayar ortamında anketleri doldurması sağlanmıştır. Araştırma evrenini Kilis, Hatay ve Gaziantep'te yaşayan 18 yaşından büyük Türkiye Cumhuriyeti vatandaşlarının oluşturduğu araştırmada, 'maliyet', 'zaman' ve özellikle Covid-19 pandemisinin etkili olduğu 'ulaşılabilirlik' kriterlerden dolayı evrenin tamamına ulaşmak mümkün olmadığı için olasılığa dayalı olmayan kolayda örnekleme tekniği kullanılarak toplam 898 katılımcı araştırma örneklemine dâhil edilmiştir. Araştırma kapsamında toplanan verilerin analizi için SPSS programından faydalanılmış; katılımcılara ait demografik özelliklerin ve toplumsal kabul ve uyuma yönelik görüş, alg1 ve tutumların tespitinde yüzde ve frekans analizlerinden faydalanılmıştır. Yüzde ve frekans analizlerinin sonuçları doğrultusunda oluşturulan grafiklere aşağıdaki başlıkta yer verilmiştir.

\section{Bulgular}

\section{Sosyo-Demografik Bulgular}

Türkiye'nin sınır kentleri Kilis, Gaziantep ve Hatay kent merkezlerinde yaşayan yerli halkın Suriyelilere ilişkin toplumsal kabul ve uyum düzeylerini ortaya çıarmak amacıyla yapılan bu araştırmanın örneklemine 898 katılımcı dâhil edilmiştir. 
Tablo 1. Katılımcıların illere göre dă̆ılımı

\begin{tabular}{lcc}
\hline Şehirler & F & \% \\
\hline Kilis & 315 & $\% 35,0$ \\
Gaziantep & 293 & $\% 32,6$ \\
Hatay & 290 & $\% 32,4$ \\
\hline Toplam & $\mathbf{8 9 8}$ & $\mathbf{0 1 0 0 , 0}$ \\
\hline
\end{tabular}

Katılımcıların il bazındaki dağılımı incelendiğinde, araştırma örneklemini Kilis ilinden 315 katılımcının (\%35), Gaziantep ilinden 293 katılımcının (\%32,6), Hatay ilinden ise 290 katılımcının (\%32) oluşturduğu görülmektedir (Tablo 1). Araştırma verilerinin toplanması sürecinde, katılımcıların iller bazında eşit dağılım göstermesine azami dikkat gösterilmiştir.

Tablo 2. Katılımcıların cinsiyete göre dă̆ılımı

\begin{tabular}{lcc}
\hline Cinsiyet & F & \% \\
\hline & & \\
Kadın & 467 & $\% 52,0$ \\
Erkek & 431 & $\% 48,0$ \\
\hline Toplam & $\mathbf{8 9 8}$ & $\mathbf{\% 1 0 0 , 0}$ \\
\hline
\end{tabular}

Araştırma örnekleminin \%52'sini kadın katılımcılar (467 kişi), \%48'ini erkek katılımcılar (431 kişi) oluşturmaktadır (Tablo 2).

Tablo 3. Katılımcıların yaş gruplarına göre dă̆ılımı

\begin{tabular}{lcc}
\hline Yaş Gruplar1 & F & \% \\
\hline & & \\
$18-24$ & 198 & $\% 22,0$ \\
$25-29$ & 220 & $\% 24,5$ \\
$30-34$ & 117 & $\% 13$ \\
$35-39$ & 114 & $\% 12,7$ \\
$40-44$ & 86 & $\% 9,6$ \\
$45-49$ & 74 & $\% 8,2$ \\
$50+$ & 90 & $\mathbf{0 1 0 0 , 0}$ \\
\hline Toplam & $\mathbf{8 9 8}$ & \\
\hline
\end{tabular}

Araştırma örnekleminin yaklaşık yarısı 18-29 yaş grubunda yer alan gençlerden oluşmakta, bu durumun sebep olarak araştırma verilerinin 
bir kısmının online anket aracılığıyla toplanması ve gençlerin teknolojiye ileri yaş gruplarına göre daha yatkın olması gösterilebilir. Ayrıca saha çalışmasının yüz yüze anket doldurma aşamasında, bu yaş grubunun araştırmaya dâhil olma konusunda diğer yaş gruplarına göre daha istekli oldukları gözlenmiştir. Tablo 3'te katılımcıların yaş gruplarına göre dağılımı incelendiğinde; katılımcların \%22'si (198 kişi) 18-24 yaş grubunu, \%24,5'i (220 kişi) 25-29 yaş grubunu, \%13'ü (117 kişi) 30-34 yaş grubunu, \%12,7'si (114 kişi) 35-39 yaş grubunu, \%9,6's1 (86 kişi) 40-44 yaş grubunu, \%8,2'si (74 kişi) 45-49 yaş grubunu ve \%10'u (90 kişi) 50 yaş ve üzerini oluşturmaktadır.

Tablo 4. Katılımcıların medeni durumlarına göre dă̆ılımı

\begin{tabular}{lcc}
\hline Medeni Durum & F & $\%$ \\
\hline Evli & 368 & $\% 41,0$ \\
Bekâr & 530 & $\% 59,0$ \\
\hline Toplam & 898 & $\% 100,0$ \\
\hline
\end{tabular}

Araştırma örneklemini oluşturan kişilerin medeni durumları incelendiğinde \% 41'inin (368 kişi) evli, \%59'unu (530 kişi) ise bekâr olduğu görülmektedir (Tablo 4). Bekâr katılımcıların sayılarının fazlalığı, örneklemdeki genç katılımcıların yoğunluğuna bağlanabilir.

Tablo 5. Katılımcıların ĕ̆itim düzeylerine göre dă̆ılımı

\begin{tabular}{lcc}
\hline Eğitim Düzeyleri & F & \% \\
\hline & & \\
Okur-yazar & 198 & $\% 3,0$ \\
Ilkkokul & 220 & $\% 20,1$ \\
Ortaokul & 117 & $\% 29$ \\
Lise & 114 & $\% 30,9$ \\
Üniversite & 86 & $\% 17$ \\
\hline Toplam & $\mathbf{8 9 8}$ & $\mathbf{0 1 0 0 , 0}$ \\
\hline
\end{tabular}

Katılımcıların eğitim durumlarına göre dağılımları incelendiğinde; katılımcların \%3'ünün (27 kişi) okur-yazar olduğu, \%20,1'inin (180 kişi) ilkokul mezunu olduğu, \%29'unun (260 kişi) ortaokul mezunu olduğu, \%30,9'sının (278 kişi) lise mezunu olduğu ve \%17'sinin (153 kişi) üniversite mezunu olduğu görülmektedir (Tablo 5). 


\section{Toplumsal Kabul ve Uyum Sürecine İlişkin Bulgular}

Toplumsal kabul ve uyum sürecinin önemli göstergeleri olan iletişim, arkadaşlık, komşuluk, alışveriş, eğitim, istihdam gibi başlıca unsurlara ilişkin katılımcıların görüş, algı ve tutumları bu bölümde ele alınacaktir.

Sosyal Etkileşim ve İletişim: Ev sahibi toplum üyelerinin, göç nedenleri ve türleri her ne olursa olsun topraklarına yerleşen "yabancı"lar ile iletişime geçmelerinin, toplumsal kabul ve uyum konusunda attıkları ilk adım olduğu düşünülmektedir. Konu ülkemizde yaşayan Suriyeliler özelinde ele alındığında, özellikle araştırma sahası olan Gaziantep, Kilis ve Hatay kentlerinde Suriyeli nüfusun fazlalığı, kamusal alandaki görünürlüklerinin her geçen gün artışı ve yerli halk ile birlikte aynı yerleşim yerlerinde yaşama süresinin fazlalığ 1 göz önünde bulundurulduğunda yerli halkın bu kişilerle iletişime girme ihtimallerinin oldukça yüksek olduğu düşünülmektedir. Özellikle Kilis'in yüzölçümünün küçüklüğü, şehir merkezinde Suriyeliler tarafından açılan işyerlerinin ve işletmelerinin fazlalığı, Suriyelilerin toplu taşıma sistemini oldukça yoğun kullanmaları, Suriyeli öğrencilerin şehrin okullarına dağılmış olması, kendi açtıkları işyerlerinde ve yerel halkın işyerlerinde aktif olarak istihdam edilmeleri hastanelerde, marketlerde, mağazalarda, şehrin çarşısında kısacası kamusal alanda görünürlüklerinin demografik fazlalıklarından ve şehrin mekânsal anlamda küçüklügünden dolayı diğer şehirlere oranla daha yüksek olduğu görülmektedir. Bu noktadan hareketle, araştırmanın anket formuna demografik sorulardan sonra, iletişimin toplumsal kabul ve uyumun ilk adımı olması da dikkate alınarak "Bugüne kadar herhangi bir Suriyeli ile iletişim kurdunuz mu?" sorusuna yer verilmiştir. 


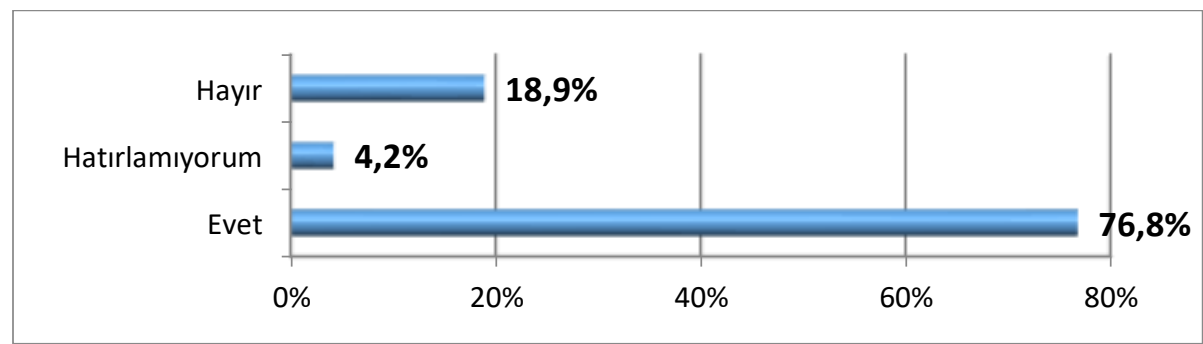

Grafik 1. "Bugüne kadar herhangi bir Suriyeli ile iletişim kurdunuz mu?" sorusuna katılımcıların verdikleri cevapların dağılımı

Katılımcıların bu soruya verdikleri yanıtlar \%76,8'i (690 kişi) evet, \%18,9'u (170 kişi) hayır ve \%4,2'si (38 kişi) hatırlamıyorum şekilde sıralanmaktadır (Grafik 1). Katılımcıların önemli bir kısmı, Suriye kökenli kişiler ile iletişime girdiklerini belirtmiştir. Anket formunda bu sorunun cevapları arasında yer alan "hatırlamıorum" seçeneğini işaretleyen arasında da Suriyelilerle iletişim kuranların bulunması muhtemeldir. Yoğun bir Suriyeli nüfusla aynı şehirde birlikte yaşamalarına rağmen bu kişilerle herhangi bir iletişim kurmadıklarını belirten katılımcı sayısı da önemli bir düzeyde olup araştırmanın beklenmedik bir sonucudur. Suriyelilerin ve yerel halkın birbirlerinin ana dillerini bilmemeleri, aralarında kurulacak etkileşim ve iletişimi zayıflatan önemli unsurlardan biri olarak düşünülebilir. Ayrıca, Suriyeli kitle ile iletişim kurmayı gerektirecek şartların henüz oluşmaması ya da yerli halktan bazı kişilerin aralarına sosyal bir mesafe koyması da iletişimin sağlanmama sebepleri arasında sayılabilir.

Ev sahibi toplum ve geçici koruma altındaki Suriyeliler arasındaki sosyal diyalog ve temasın daha üst seviyelerdeki yansıması sayılabilecek komşuluk, arkadaşlık ve dostluk ilişkileri de araştırma kapsamında ele alınmıştır. Katılımcılara yöneltilen "Suriyeli komşularını/arkadaşlarını/dostlarınız var mı?" sorusuna verilen yanitların oransal dağılımına Grafik 2' de yer verilmiştir.

Grafik 2'deki veriler incelendiğinde, katılımciların yarısından fazlasının $(\% 55,3)$ Suriyelilerle komşuluk/arkadaşlık/dostluk bağı kurdukları, yarısına yakının $(\% 44,7)$ ise bu bağı kurmadıkları görülmektedir. Araştırma kapsamında sınır kentlerde yaşayan yerli halktan seçilen örneklemden hareketle ve araştırma verilerinden hareketle, Suriye 
kaynaklı zorunlu kitlesel göç hareketinin üzerinden geçen yıllarla birlikte yerli halk ve Suriyeli kişiler arasındaki ilişkinin kuvvetlendiği söylenebilir. Ancak anket sorusundan yer alan "komşularını" ifadesiyle yerel halkın yakın ilişki kurdukları ve sosyal diyalog içerisinde oldukları Suriyeli komuşularının varlığı anlatılmak istenmiş, araştırma örnekleminin ise herhangi bir sosyal diyaloğa girmedikleri sadece aynı mahallede/apartmanda oturdukları Suriyelilerin varlığını dikkate aldıkları görülmektedir.

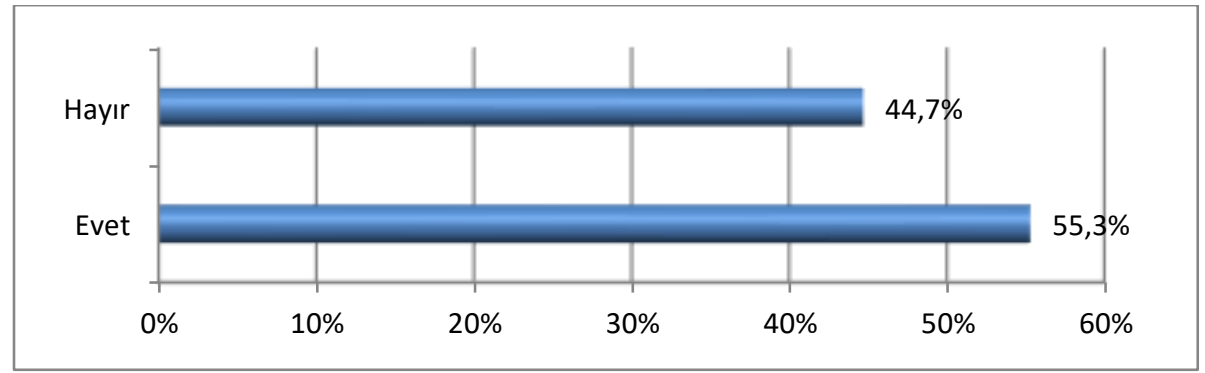

Grafik 2. "Suriyeli komşularınız/arkadaşlarını/dostlarınız var mı?" sorusuna katılımcıların verdikleri cevapların dă̆ılımı

Ev sahibi toplum ve göç eden topluluk arasında iletişimi ve toplumsal kabulü arttıran önemli unsurlardan biri, yukarıda da değinildiği üzere, şüphesiz konuşulan ortak dildir. Ev sahibi toplumun anadilini öğrenmek, göçle gelen kişilere pek çok avantaj sağlamaktadır. İki grup arasında diyaloğun gelişmesi, ortak ekonomik, sosyal, kültürel faaliyetlerin yürütülmesi, arkadaşlık ilişkilerinin gelişmesi ve uyum içerisinde bir yaşam sürdürülebilmesi için dil oldukça önemlidir. Özellikle sınır kentlerde Suriyelilere yönelik kamu kurumlarının ve sivil toplum örgütlerinin açtıkları Türkçe dil ve okuma-yazma kursları bulunmaktadır. Bu kurslara Suriyeli kursiyerlerin katıldığ 1 gözlenmektedir. Her kademe eğitim kurumlarında ise Suriyeli çocuklar ve gençler Türkçe müfredata göre yerli akranlarıyla birlikte eğitim almakta, aynı zamanda bu eğitim kurumlarında yerli öğrenciler ve öğretmenlerle kaynaşarak Türkçe öğrenme fırsatı elde etmektedirler. Ayrıca yerli okullarda Suriyelilere yönelik Türkçe hazırlık dil kursları da faaliyet göstermektedir. Yerli halkla gündelik yaşam içerisinde kurulan ilişki de ülkemizde yaşayan 
Suriye kökenli kişilere Türkçeyi öğrenme konusunda bir fırsat olarak değerlendirilmektedir. Zorunlu kitlesel göçün üzerinden geçen yılların fazlalığ öğrenme meselesini daha önemli kılmaktadır. Bu doğrultuda, Suriyelilerin ülkemizde geçirdikleri zaman zarfında Türkçeyi öğrenme konusundaki istek ve hevesleriyle ilgili araştırma örnekleminin gözlemlerine ve görüşlerine başvurulmuştur.

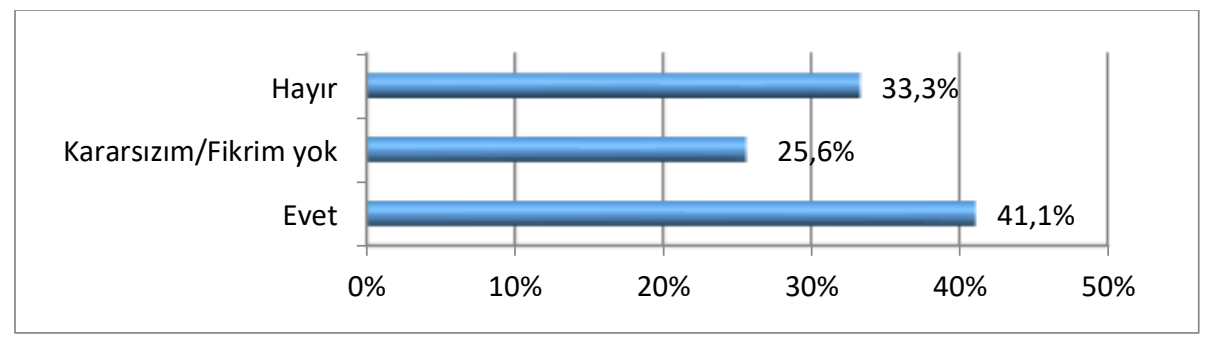

Grafik 3. "Suriyelilerin Türkçeyi öğrenme konusunda hevesli olduklarını düşünüyor musunuz?" sorusuna katılımcıların verdikleri cevapların dağıllımı

Katılımcıların \%41,1'i Suriyelilerin Türkçeyi öğrenme konusunda çaba gösterdiklerini düşünmektedir. Katılımcıların \%33,3'ü bu konuda olumsuz görüş bildirirken \%25,6'sının Suriyelilerin Türkçe öğrenmeleri ile ilgili isteklerinden ve eylemlerinden haberdar olmadıkları görülmektedir (Grafik 3). Suriyelilerin uyum sürecinde Türkçe dilinin ikili bir önemi olduğu ifade edilmektedir. Bu süreçte Türkçe bilmek bir yandan uyum için çok önemli bir araç ve avantaj teşkil etmekte, diğer yandan dil bilmemek Suriyelilerin Türkiye'de toplumla etkileşim içine girmesini engelleyen, onları izolasyona iten bir unsur ve uyumun önünde duran bir bariyer olarak görülmektedir. Türkçe konuşabilmek bir Suriyelinin Türkiye'ye uyum sağladığını kanıtlayan en temel göstergelerin başında görülmektedir (Erdoğan, 2020:, s. 108). Katılımcıların önemli bir kısmının (yaklaşık \%60'ının), Suriyelilerin Türkçe öğrenme konusundaki çabalarıyla ilgili olumlu görüş bildirmemesi, toplumsal kabul ve uyumun önünde bir engel teşkil edebilecek önemli bir unsur olarak değerlendirilebilir. Bu noktada, Suriyelilere önemli bir görev düşmekte, Türkçeyi öğrenme çaba ve eylemlerini arttırmaları gerekmektedir. 
Ekonomik İlişkiler: Savaşa bağlı kitlesel göç sonrası ülkemize dört milyona yakın Suriyelinin yerleşmesiyle Türkiye'de yaşanan demografik değişim, ekonomik değişimleri de beraberinde getirmiştir. Özellikle sınır kentlerde ikâmet eden Suriyeli kitlenin işgücü piyasasına girişiyle birlikte, yerli çalışanlarla iş ve ücret konusunda rekabet meselesi ortaya çıkmıştır. Suriyeli işgücünün bu şehirlerde çalışma yaşamına dâhil olması ve yerli işverenler tarafından ucuz işgücü olarak etiketlenmeleriyle birlikte, inşaat ve tarım sektörleri başta olmak üzere pek çok işte istihdam edilmeleri söz konusu olmuştur. Bu durum, bu sektörlerde çalışan yerli işgücünün memnuniyetsizliğine neden olmuştur. Aynı zamanda, Suriyeli girişimcilerin özellikle Kilis'te olmak üzere diğer sınır kentlerde de küçük ve orta büyüklükte açtıkları işyerleri, dükkânlar ve mağazalar yerli esnafın hoşuna gitmemiştir. Bu tür dükkânlara Suriyeli kitlenin 'hemşehricillik' bağlarından hareketle, yoğun bir talep göstermesi ile birlikte, Suriyeli esnafın yüzü gülmüş ve ticari anlamda bu şehirlerde tutunmayı başarmışlardır. Yerli müşterilerin de zaman zaman bu işletmeleri tercih etmeleri ise beraberinde yerli ve Suriyeli esnaflar arasında rekabeti tutuşturmuştur. Bu ve benzeri yaşanan olaylar sonucunda, Suriyeli göçü, ekonomik anlamda pek çok değişimi beraberinde getirmiştir. Araştırma örneklemine, yukarıda sıralanan konularla ilgili sorular yöneltilerek fikirleri ve tutumları ortaya çıkarılmaya çalışılmıştır. Katılımcılara yöneltilen "Suriyelilerin yaşadığınız şehirde herhangi bir işte çalışmasından veya işyeri açmalarından rahatsız olur musunuz?" sorusuna verdikleri yanıtların oransal dağılımı Grafik 4'te yer almaktadır.

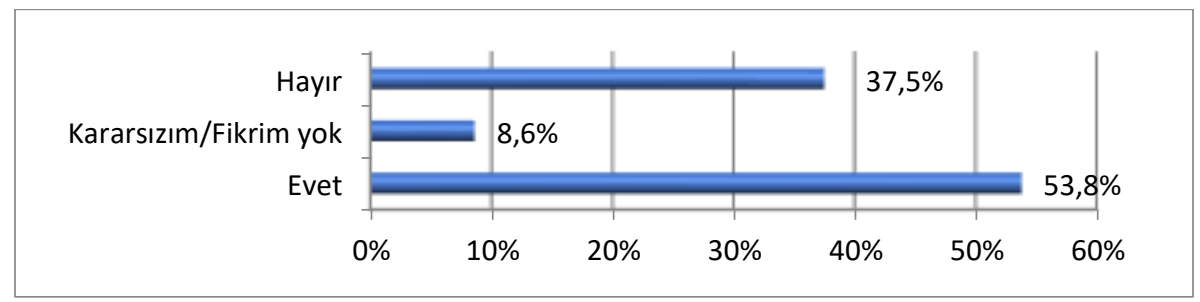

Grafik 4. "Suriyelilerin yaşadı̆̆ım şehirde herhangi bir işte çalışmalarından ya da işyeri açmalarından rahatsız olur musunuz?" sorusuna katılımcıları verdikleri cevaplar 
Katılımcıların \%53,8'i yaşadıkları şehirde Suriyelilerin ekonomik faaliyette bulunmalarına sicak bakmazken, \%37,5'inin konuyla ilgili olarak pozitif bir tutuma sahip oldukları, kalan $\% 8,6$ 'sının ise pozitif veya negatif herhangi bir görüşe sahip olmadı̆g 1 görülmektedir (Grafik 4). Ülkemizde yaşamını sürdüren Suriyelilerin çalışma yaşamına katılması, ekonomik bir faaliyette bulunması ve kendi ekonomik geçimini sağlaması Türkiye'nin Suriyelilerle ilgili yüklendiği ekonomik külfeti azaltacaktır. Geçici koruma altındaki yaklaşık dört milyonluk Suriyeli kitlenin işgücü piyasasına girmemesi, kendi ayakları üzerinde duramamalarına dolayısıyla Türkiye Cumhuriyeti devletine ve Suriyelilere yardım konusunda ülkemize fon sağlayan yabancı yardım kurum ve kuruluşlarına bağımlı bir yaşamı beraberinde getirecektir. Sokaklarda dilencilik yapan çocuk ve yetişkinlerin sayısını da arttıracaktır. Ayrıca istihdam, ülkemize uyum konusunda da önemli bir araç olarak değerlendirilebilir. Suriyelilerin ülkemiz istihdamına katılmaları bu açılardan değerlendirildiğinde oldukça önemli görünmektedir. Ayrıca, yerli ve Suriyeli esnaflar arasındaki rekabet, bu yerleşim yerlerindeki müşteriler açısından olumlu bir gelişme olarak değerlendirilebilir. Ancak, konuya yerli çalışanlar ve esnaf açısından bakıldığında, olumsuz bir tablo karşımıza çıkmaktadır. İş ve ücret rekabeti, yerli çalışanları ve esnafı olumsuz etkilemektedir. Anket formunda yer alan bir sonraki soruya verilen cevaplar ise, yukarıdaki soruya verilen cevaplarda olduğu gibi, ekonomik faaliyetler ilgili katılımcıların fikir ve tutum birliği içerisinde olmadıklarını göstermektedir.

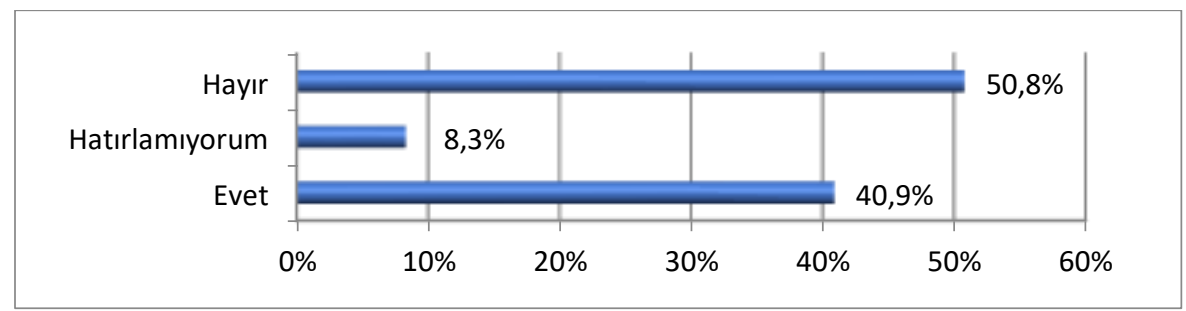

Grafik 5. "Suriyelilerin yaşadığınız şehirde açmış oldukları dükkânlardan alışveriş yaptınız mı?" sorusuna katılımcıların verdikleri cevapların dağılımı

Araştırma kapsamında katılımcılara, "Suriyelilerin yaşadığınız şehirde açmış oldukları dükkânlardan alışveriş yaptınız mı?" sorusu yöneltilmiş ve 
soruya verilen cevaplar; \%50,8 (456 kişi) hayır, \%40,9 (367 kişi) evet, \%8,3 (75 kişi) hatırlamıyorum şeklinde dağılım göstermiştir (Grafik 5). Suriyeli esnaflardan alışveriş yapan yerli müşteriler olmakla birlikte, bu dükkânlardan alışveriş yapmayan yerli müşteriler de bulunmaktadır. Bu durum, yerli esnafın müşterilerinden bir kısmının artık alışverişlerinin bir bölümünü veya tamamını Suriyeli esnaftan yaptığını, böylece yerli esnafın aleyhine bir durumun ortaya çıktığını göstermektedir. Bununla birlikte, Suriyeli esnafın ve çalışanların Türk işgücü piyasasındaki aktifliği, yerli işverenler ve yerli müşterilerle yaşadıkları teması ve etkileşimi arttırmaktadır. Böylece yaşanan bu gelişmeler, yerli halkın Suriyelilere yönelik toplumsal kabul ve uyum düzeylerini arttıran unsurlar olmaktadır. Suriyelilerin ülkemizde ve yoğun olarak sınır kentlerde sürdürdükleri ekonomik faaliyetler, toplumsal kabul ve uyum konusunda önemli bir adım olarak değerlendirilebilmektedir.

Mekânsal Yakınlık: Göç, meydana geldiği yerin nüfus yapısını etkilediği gibi oranın yerleşme yapısını da etkilemektedir (Eşim, 2020, s.97). Ulusal ve uluslararası nitelikte, bireysel ve kitlesel nüfus hareketi olarak gösterilen ve tüm tanımlamalar ile karmaşık bir yapıya sahip olan göç (Çelik, 2012, s.8), belli bir zaman ve mekandaki insanların gönüllü, veya gönülsüz, sosyal veya siyasi nedenlerden dolayı mekan değişikliğini içeren bir eylem olup; bu eylemin sonucunda sosyo-kültürel etkileşimlerin ve değişimlerin meydana geldiği bir sosyal hareketlilik olarak gösterilmektedir (Türkyılmaz vd., 1998, s.3). Ve nihayetinde her değişme belli bir coğrafik alanda gerçekleşmektedir. Bu nedenle mekân boyutu da toplumsal değişmenin ortaya çıkmasında ve gelişmesinde olmazsa olmaz unsurlardan biridir. Bu bağlamda toplumsal değişmenin insan, zaman ve mekân olarak üç temel öznesi bulunmaktadır. (Doğan, 2012, s.224).

Göçün toplumsal ve mekânsal yapıya etkisi göçün gerekçesine göre farklılaşmakta, özellikle zorunlu göçlerde, göçmenlerin kente hazırlıksız gelmesi, geldikleri yeni yerleşim biriminde sosyo-ekonomik birtakım problemler yaşamalarına neden olmaktadır. Bu durumun en temel sonuçlarından biri de, sosyal ayrışmalardır. Göçmenlerin ve ev sahibi toplumun ayrışmasının mekânsal yapıdaki ifadesi ise, yaşam alanlarının ayrışmasıdır. Bu durumda göçmenler, güvende hissetme güdüsü ile 
kendi profillerine benzer insanlarla birlikte yaşama eğilimi göstermektedir. Bu nedenle mekânsal birlikteliklerde etno-kültürel ve/veya sosyoekonomik benzerlikler son derece etkilidir (Tümtaş ve Ergun, 2016, s.1353). Bu tespitin özellikle ülkemizdeki Suriyeliler açısından geçerliliğini korumakla birlikte, göç hareketinin ilk yıllarında daha etkili olduğu söylenebilir. Suriyeliler ülkemize giriş yaptıktan sonra bir kısmı geçici barınma merkezlerine yerleşmişler, diğer kısmı şehir merkezlerinde barınmak durumunda kalmıştır. Geçen yıllarla birlikte, bazı geçici barınma merkezlerinin kapatılması, diğerlerinin de kapasitesinin azaltılmasıyla birlikte, Suriyelilerin çok büyük kısmının Türkiye'nin şehir merkezlerine dağıldıkları görülmektedir ${ }^{1}$. Sınır kentlerden Kilis, Gaziantep ve Hatay'da Suriyelilerin büyük bir kısmı birbirlerine yakın mahallelerde ikâmet etmekle birlikte, göçün ilk yıllarına göre şehir merkezlerindeki farklı mahallelere dağıldıkları gözlemlenmektedir. Göç sonrası yerleşimin ilk zamanlarında birbirlerine yakın evlerde ve belirli mahallelerde yoğunlaşmakla birlikte, aradan geçen yıllarla birlikte Suriyelilerin hem artan nüfusları hem yaşadıkları şehirleri tanımaları hem de ülkemizdeki kalıcılık eğilimlerindeki artışla birlikte şehirlerin farklı noktalarına dağıldıkları görülmektedir. Ancak yine de etno-kültürel ve sosyo-ekonomik benzerliğe dikkat edilmektedir. Sınır kentlerin yerli halkının Suriyelilerle kurmak durumunda kaldıkları mekânsal yakınlığa dair görüşleri ve tutumları ise, özellikle toplumsal kabul ve uyum noktasında oldukça önemli görülmektedir. Bu durum, toplumsal kabul ve uyumu odak noktasına alan bu çalışmada göz ardı edilmemiş ve araştırma kapsamında hazırlanan anket formuna konuyla ilgili soruların yerleştirilmesini gerekli kılmıştır.

\footnotetext{
${ }^{1}$ Türkiye'de aktif olarak faaliyet gösteren geçici barınma merkezlerinde yaşamını sürdüren Suriyeli sayısı sırasıyla Adana'da 20.650 kişi, Hatay'da 9.146 kişi, Kahramanmaraş'ta 10.415 kişi, Kilis'te 8.490 kişi ve Osmaniye'de 9.245 olmak üzere toplam 57.946 kişidir (GIGM, 10.03.2021).
} 


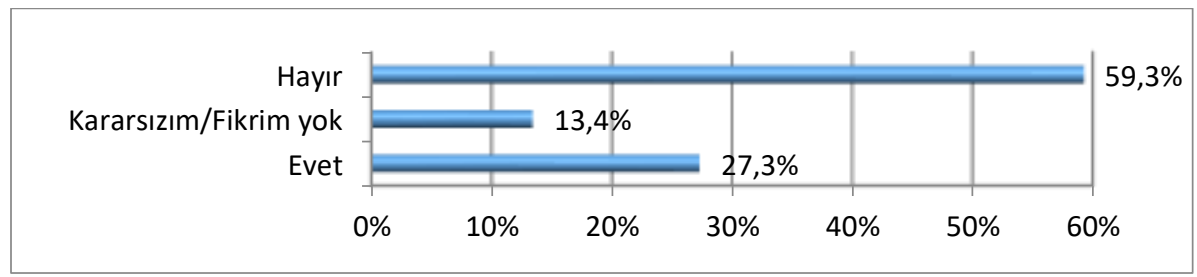

Grafik 6. "Suriyelilerin yaşadı̆̆ınız şehrin bazı mahallelerinde toplu olarak yaşaması gerektiğini düşünüyor musunuz?" sorusuna katılımcıların verdikleri cevapların dağılımı

Araştırma örneklemini oluşturan kişilere "Suriyelilerin yaşadığınız şehrin bazı mahallelerinde toplu olarak yaşaması gerektiğini düşünüyor musunuz?" sorusu yöneltilmiş ve verdikleri cevapların yüzdelik dağılımı Grafik 6'da gösterilmiştir. Bu soruya katılımcıların

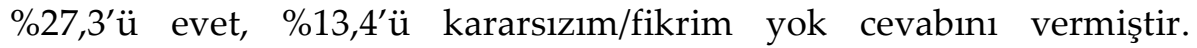
Katılımcıların \%59,3'ü ise, Suriyelilerin, yerli halktan ayrı ve kopuk bir şekilde şehrin belirli semtlerinde toplu olarak yaşamalarını doğru bulmamaktadır. Başka bir deyişle, örneklemin yarısından biraz fazlası, Suriyelilerin yaşadıkları şehirlere dağılmaları ve yerli halkla iç içe yaşamaları gerektiğini düşünmektedirler. Ancak, Suriyelilerin yaşadıkları şehirde yerli halktan ayrı semtlerde, mekansal olarak uzakta yaşamalarını gerektiğini düşünen katılımcıların oranının da azımsanmayacak bir düzeyde olduğu görülmektedir. Araştırma sonucunda ortaya çıkarılan bu görüş, toplumsal kabul ve uyum anlamında yerli halkın bakış açısı ve tutumunun yönünü yansıtması açısından önemli görülmektedir.

Kilis, Gaziantep ve Hatay yerli halkından kişilerin oluşturduğu araştırma örnekleminin yarısından biraz fazlası, yukarıda belirtildiği üzere, Suriyelilerin gettolaşmasını uygun bulmamakta doğal olarak bu kişilerle komşu olabileceklerini ifade etmektedirler. Peki, örneklemi oluşturan bu kişiler, Suriyelilerin yoğun olarak yaşadıkları bir apartmanda yaşamak konusunda ne düşünmektedirler? 


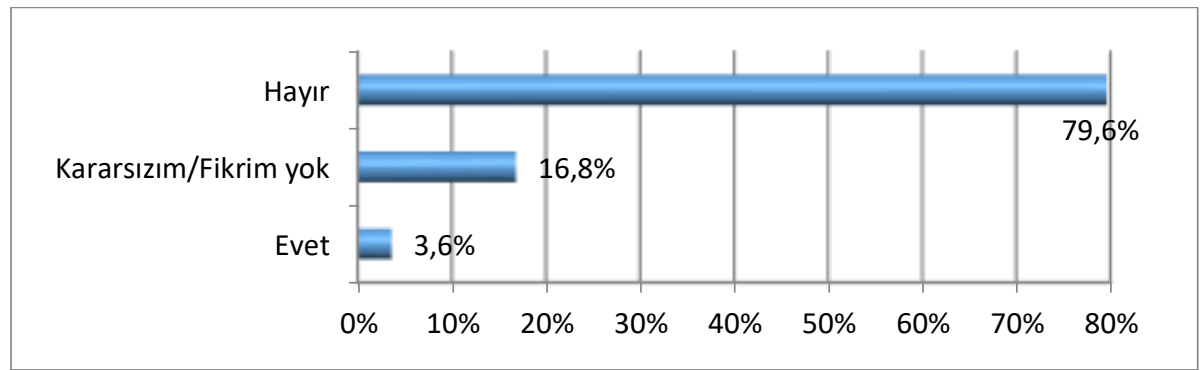

Grafik 7. "Suriyeli ailelerin yoğun olarak yaşadığı bir apartmana taşınmak ister misiniz?" sorusuna katılımcıların verdikleri cevapların dă̆ılımı

Katılımciların sadece \%3,6'si bu soruya evet cevabını verirken, $\% 16,8$ 'i konuyla ilgili kararsız kalmıştır. Katılımcıların \%79,6'sı Suriyeli ailelerin yoğun olarak yaşadıkları bir apartmana taşınmak istemediklerini ifade etmişlerdir (Grafik 7). Grafik 6 ve 7'de yer alan veriler birlikte değerlendirildiğinde, yerli halkın bir kısmının Suriyelilerin şehrin farklı semtlerinde yaşamalarında doğal olarak komşu olma ihtimallerinde sorun görmezken, yerli halkın büyük bir kısmı aynı apartmanda yaşamaya ve daha fazla bir mekânsal yakınlığa sıcak bakmadıkları söylenebilir. Burada dil, etnik köken, kültür farkı kısacası yaşam tarzı farkı devreye girmekte ve toplumsal kabul ve uyum konusunda Suriyeliler ve yerli halk arasında atılması gereken adımlara ve zamana ihtiyaç duyulduğu görülmektedir.

Çocuklarla Yakın İlişki: Yerel halkın aile üyeleriyle Suriyelilerin kuracakları yakın sosyal ilişkilere bakışları da toplumsal kabul ve uyum konusunda önem taşımaktadır. Bu amaçla, araştırma kapsamında örneklemi oluşturan kişilere, aile üyelerinin (çocukları, kardeşleri vb.) ile Suriyelilerin kuracakları arkadaşlık, dostluk, evlilik gibi oldukça yakın teması içeren ilişkilere ne tepki verecekleri sorulmuştur. Bu sorulardan ilki, katılımcıların çocukları ile Suriyeli çocukların bir eğitim kurumunda, aynı sınıfta eğitim görmesinden rahatsızlık duyup duymayacaklarıdır. Bilindiği üzere, Suriyeli çocuklar ve gençler, farklı eğitim kademelerinde yerli akranlarıyla birlikte aynı eğitim kurumlarında aynı sıralarda eğitim görmektedirler. Özellikle sınır kentlerde faaliyet gösteren okul öncesi sınıflarda, ilkokullarda, ortaokull- 
arda, liselerde hatta üniversitelerde oldukça yoğun bir Suriyeli öğrenci kitlesi bulunmaktadır. Bu okullarda, Suriyeli öğrenciler yerli öğrencilerle aynı sınıfta, aynı sıralarda, Milli Eğitim Bakanlığı müfredatına göre, Türkçe dilinde, yerli öğretmenlerden Türkçe eğitim almaktadırlar. Böylece Suriyeli öğrencilerin eğitimlerine ara vermeleri engellenmekte, Türk eğitim sistemine entegre edilmelerine çaba sarf edilmekte, toplumsal uyum ve kaynaşma amaçlanmakta, Türkçe dil becerileri arttırılmaya çalışılmakta ve kayıp bir nesil olmalarının önüne geçilmeye çalışılmaktadır.

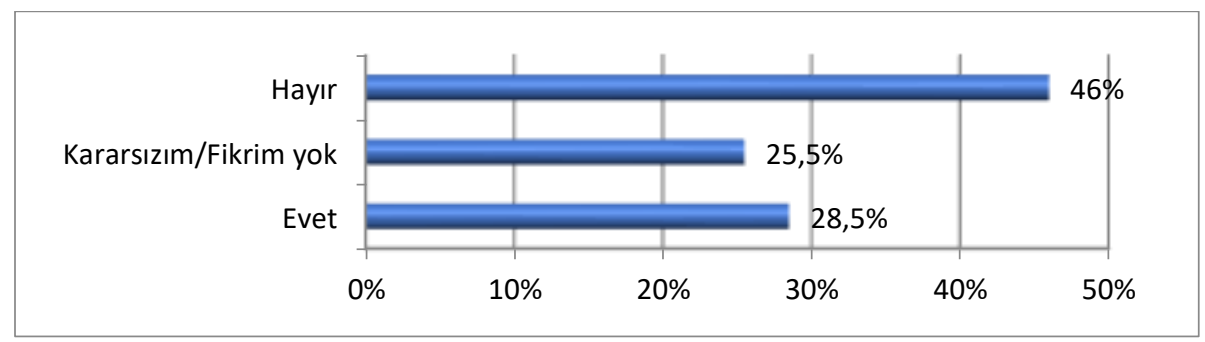

Grafik 8. "Çocuğunuzun, Suriyeli çocukların olduğu sınıfta eğitim görmesinden rahatsız olur musunuz?" sorusuna katılımcıların verdikleri cevapların dağılımı

Araştırma örneklemine, "Çocuğunuzun, Suriyeli öğrenciler ile aynı sinıfta eğitim görmesinden rahatsız olur musunuz?" şeklinde bir soru yöneltilmiş ve verilen cevaplara Grafik 8 'de yer verilmiştir. İlgili soruya katılımcların \%46'sı (413 kişi) hayır cevabını, \%28,5'i evet cevabını, \%25,5'i (229 kişi) ise kararsızım/fikrim yok cevabını vermiştir (Grafik 8). Suriyeli çocuk ve gençlerin, yerli akranlarıyla ve ev sahibi toplumla kaynaşması ve uyumu konusunda önemli bir unsur olan birlikte eğitim konusunda, katılımcıların yaklaşık yarısının konuya pozitif yaklaştıkları görülmektedir.

Araştırma kapsamında örneklemin, Suriyeli çocuklarla yerli çocukların arkadaşlık/dostluk kurma konusundaki görüşleri de ortaya çıkarılmıştır. 


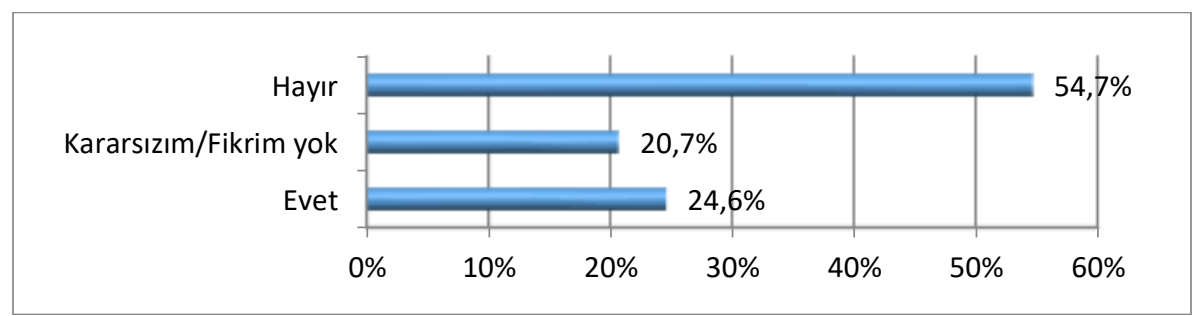

Grafik 9. "Çocuğunuzun, Suriyeli çocuklarla arkadaş olmasından rahatsız olur musunuz?" sorusuna katılımciların verdikleri cevapların dă̆ılımı

Grafik 9'da görüleceği üzere, araştırma örnekleminin \%54,7'si (491 kişi) çocuklarının Suriyeli çocuklarla arkadaş olmasından rahatsızlık duymayacağını belirtirken, \%24,6'sı (221 kişi) bu ilişkiye sıcak bakmamış, \%20,7'si (186 kişi) ise pozitif veya negatif herhangi bir yönde fikir beyan etmemiştir.

Evlilik ve Aile Kurma: Evlilik, ülkesinden ayrılarak göç yoluyla başka bir ülkeye yerleşen kişilerin toplumsal kabul ve uyum sürecinde önemli bir adımdır. Ev sahibi toplum üyeleriyle yapılan evlilikler, söz konusu ülkede göçmen/mülteci/geçici korunan gibi hukuki statülerde bulunan kişilerin kalıcı yasal statüye/vatandaşlığa kabulünde ve toplumsal uyumda oldukça etkili bir yol olarak görülmektedir. Özellikle göçmen kadınların gittikleri ülkede yasal engelleri aşmak ve/veya daha güvenli bir yaşam sürdürebilmek için evliliği tercih etmeleri yaygın olarak görülmektedir. Ülkelerin değişen göç politikalarına bağlı olarak, oturum izni ve vatandaşlık elde etme prosedürleri zorlayıcı olmaktadır. Aile kurumu, eşlerin bir arada kalmasına olanak sağlarken göçmen kadınların göç ettikleri ülkede bulunmalarına yasal dayanak olmaktadır. Evlilik aynı zamanda, yasal ve toplumsal kabulün yolunu açarak güvenlik ihtiyacını karşılayan bir özelliğe sahiptir. Sebepler, farklı göç deneyimlerinde benzer olabileceği gibi, zorunlu göçle birlikte yapılan evlilikler gidilecek başka bir yerin (evin) olmaması gerçeğinden dolayı yasal, toplumsal ve duygusal boyutları bakımından farklılaşmaktadır. Suriye'deki savaş ile başlayan zorunlu göç sonrası Suriye vatandaşı kadınların yaptıkları evliliklerde, evliliğin hangi koşullarda gerçekleştiği, nedenleri, toplumsal ve yasal statüler açısından kazanımları gibi boyutlar birçok yönüyle değişmektedir (Gönül, 2020, s.87). 
Türkiye ve Suriye vatandaşlarının zorunlu göç ile farklılaşan ilişkileri, kültürel, sosyal ve ekonomik yönlerden çok boyutludur. Zorunlu göç, ülke içinde yaşanan birçok toplumsal sorunun dışında iki halkın arasında yeni bağlar kurmuştur. Aile ve akrabalık ilişkileri yeni olmasa da güçlenen bağlardan biridir. Türkiye ve Suriye vatandaşları arasında gerçekleşen evlilikleri ele aldığımızda karşımıza hem tarihsel olarak sınır illerindeki ilişkiler hem de dinsel ve kültürel ortaklıklar çıkmaktadır. Suriye ile Türkiye'nin sınır illerinde uzun yıllardır süregelen iş ve ticarete dayalı ilişkiler, dinsel ve dilsel ortaklıklar, akrabalıklar gibi tarihsel ilişkilerden dolayı iki toplum arasında evlilikler yeni bir olgu değildir. 2011 sonrasında Türkiye'ye gelen Suriyeli kadınların yerli erkeklerle yaptıkları evlilikleri, bu tarihsel ilişkinin uzantısı olan evliliklerden farklılaştıran nokta ise, yeni evliliklerin savaş ve zor yaşam koşullarına karşı bir çözüm olarak düşünülmesidir (Gönül, 2020, s.86).

Türkiye İstatistik Kurumu'nun (TÜIK) yayınladığı Erkek ve Kadının Uyruğuna Göre Evlenmeler Raporu (2009-2020) verileri incelendiğinde, Suriye vatandaşı kadın ve erkeklerin ülkemizde Türkiye Cumhuriyeti vatandaşlarıyla evlendikleri görülmektedir. Suriye kökenli kadınların özellikle 2012 yılı ve sonrasındaki yıllarda, Türkiye'deki yabancı uyruklu kadınlar sıralamasında ilk sırada yer almaları oldukça dikkat çekicidir. Suriye kökenli erkeklerin, Türkiye Cumhuriyeti vatandaşı kadınlarla yaptıkları evlilikler de Tablo 6'da görüleceği üzere, azımsanmayacak düzeydedir.

Tablo 6. Geçici koruma kapsamındaki Suriyelilerin T. C. vatandaşlarıla Türkiye'de yaptıkları resmi evliliklerin yıllara göre dă̆ılımı (2011-2020)

\begin{tabular}{lccccccccccc}
\hline Yil & $\mathbf{2 0 1 1}$ & $\mathbf{2 0 1 2}$ & $\mathbf{2 0 1 3}$ & $\mathbf{2 0 1 4}$ & $\mathbf{2 0 1 5}$ & $\mathbf{2 0 1 6}$ & $\mathbf{2 0 1 7}$ & $\mathbf{2 0 1 8}$ & $\mathbf{2 0 1 9}$ & $\mathbf{2 0 2 0}$ & Toplam \\
\hline Kadın & 1483 & 694 & 873 & 2049 & 3569 & 6495 & 4074 & 3637 & 3142 & 2798 & $\mathbf{2 8 . 8 1 4}$ \\
Erkek & 105 & 58 & 106 & 143 & 241 & 377 & 323 & 560 & 760 & 734 & $\mathbf{3 . 0 4 7}$
\end{tabular}

Kaynak: TüİK Erkek ve Kadının Uyruğuna Göre Evlenmeler Raporu (2009-2020).

Suriye Arap Cumhuriyeti vatandaşlarıyla evlilik konusu yukarıda belirtildiği üzere, geçmişten günümüze gelen bir olgu olmakla birlikte, zorunlu kitlesel göç hareketi sonrası farklı boyutlar kazanmıştır. 2011 
yılı ve sonrası, farklı etnik köken ve kültürden kişiler arasında yapılan resmi evliliklerin ve kurulan aile bağlarının, Suriyeli gelin ve damatların ülkemizdeki toplum kabul ve uyum süreçlerine olumlu etki yapması beklenmektedir. Bu evliliklerin varlığı ve uyum üzerindeki etkisi ise, konunun araştırma kapsamında ele alınmasını gerekli kılmış ve araştırma örneklemine, "Aile üyelerinizden birinin (çocuğunuz, kız velveya erkek kardeşleriniz) Suriye kökenli bir bireyle evlenmesinden rahatsız olur musunuz?" sorusu yöneltilmiştir.

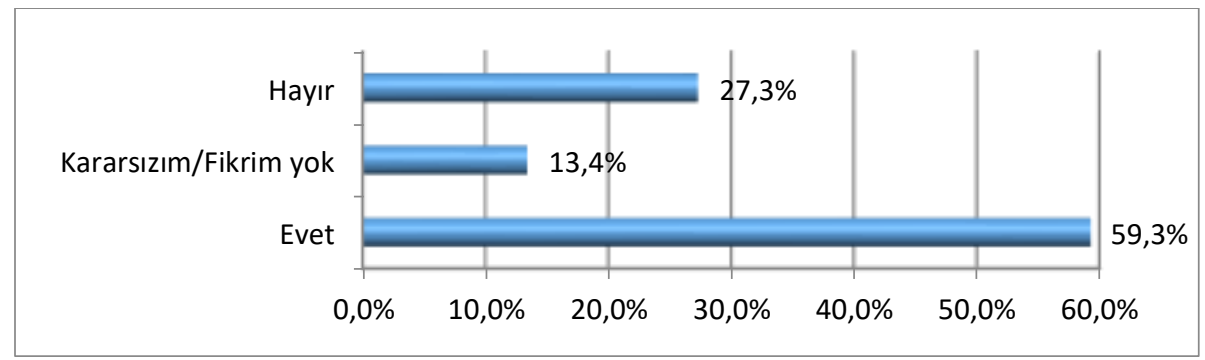

Grafik 10. "Aile ïyelerinizden birinin (çocuğunuz, kız/erkek kardeşiniz) Suriye kökenli bir bireyle evlenmesinden rahatsız olur musunuz?" sorusuna katılımcıların verdikleri cevaplarin dă̆ılımı

Grafik 10 'da, araştırma örnekleminin \%59,3'ünün, aile üyelerinin, hayatlarını evlilik bağıyla Suriyeli bireylerle birleştirmesine olumlu yaklaşmadıkları görülmektedir. Örneklemin \%27,3'ü çocuklarının ve/veya kardeşlerinin, Suriye kökenli kişilerle evlenmelerinden rahatsızlık duymayacaklarını belirtirken, \%13,4'ü konuyla ilgili olarak herhangi bir karara varamamıştır. Örneklem içerisinde kendi çocuklarının ve/veya kardeşlerinin, geçici koruma kapsamındaki Suriyelilerle evlenmesine, bu evlilik neticesinde aileler arası kurulacak yakın temasa ve akrabalık ilişkisine sıcak bakanların yanı sıra konuya nötr yaklaşanların varlığı, araştırma sonucunda toplumsal kabul ve uyum konusunda bir ilerleme sağlandığının varlığına işaret olarak gösterilebilmektedir.

Birlikte Yaşama Kültürü: İlk kafileden bu yana milyonlarca insan Türkiye'ye giriş yapmış ve sınır bölgeleri ağırlıkta olmak üzere Türkiye'nin birçok iline dağılmışlardır. Dört milyona yakın nüfusun ülke 
coğrafyasına dağılmış olmasının, onların görünürlüğünü ve etkilerini azaltacağı düşünülse de, Suriyeli kitlenin büyükşehirlerde ve sınırdaki kentlerde yoğunlaşmaları bu durumu tersine çevirmektedir (Orhan ve Gündoğar, 2015, s.16). Suriyelilerin sınır kentlerdeki değişime etkisi konusunda bizzat bu bölgede yaşayan yerli halkın görüşleri bu nedenle oldukça önemlidir.

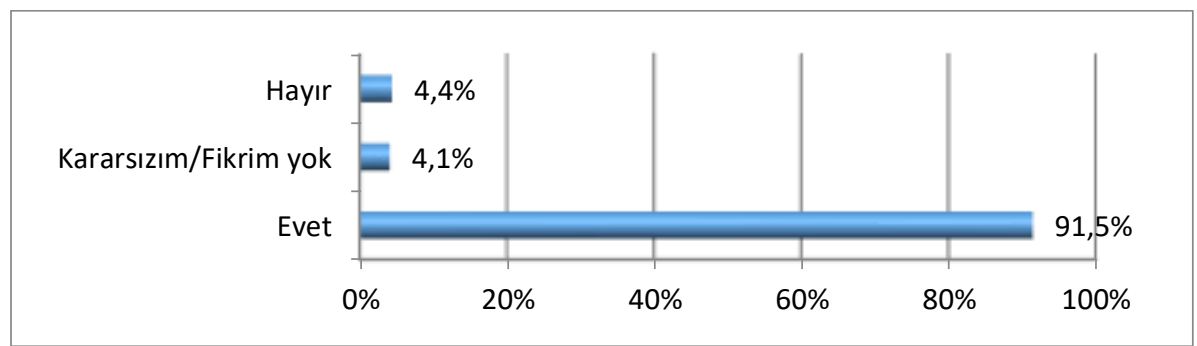

Grafik 11. "Suriyeliler geldikten sonra yaşadığını şehirde değişiklikler olduğunu düşünüyor musunuz?" sorusuna katılımcıların verdikleri cevapların dağılımı

Kilis, Gaziantep ve Hatay yerli halkından kişilerin oluşturduğu araştırma örnekleminin \%91,5'i, Suriyelilerin gelişlerinin yaşadıkları şehirlerde değişikliklere neden olduğunu, \%4,4'ü Suriyeli göçünün, yaşadıkları sınır kentlerde herhangi bir değişikliğe sebep olmadığını düşünmektedir. Katılımcıların kalan \%4,1'inin ise, Suriye kaynaklı zorunlu kitlesel göç sonrası Suriyelilerin sınır kentlere yerleşmelerinin, yaşadıkları şehirlerde bir değişime neden olma konusunda herhangi bir fikre sahip olmadıkları görülmektedir (Grafik 11). Katılımcıların neredeyse tamamı Suriyeli kitlenin şehirlerinin yapısına etki ettiklerini düşünmelerine dolayısıyla bu kişilerin şehirlerindeki varlıklarını kabul etmelerine ragmen, Grafik 12' de yer alan veriler, geçici korunanlarla birlikte yaşamaya alışma noktasında farklı düzeyde oldukları görülmektedir. 


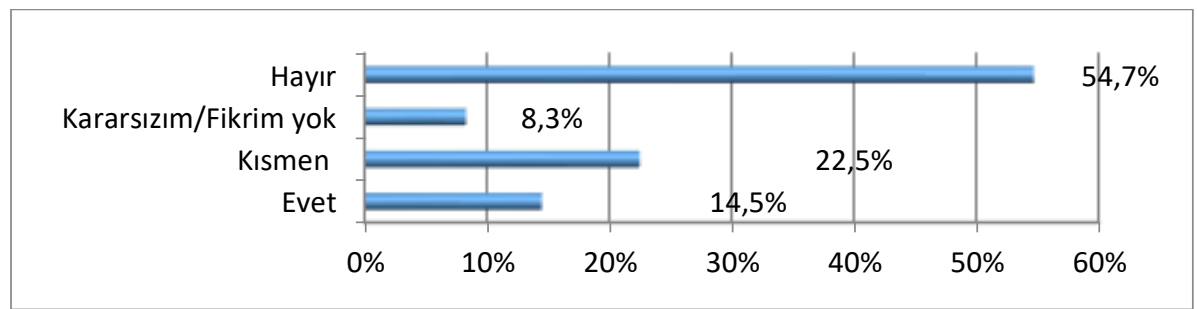

Grafik 12. "Suriyeliler ile aynı şehirde birlikte yaşamaya alıştınız mı?" sorusuna katılımcıların verdikleri cevapların dă̆ılımı

Kilis, Hatay ve Gaziantep şehirleri ve bu şehirlerde yaşayan yerel halk, zorunlu göçün başladığ Suriyeli ile yoğun bir temas halindedir. Bu zaman diliminde kesintisiz bir şekilde Suriyeliler ile etkileşim halinde olan yerel halkın, şehirlerinde yaşayan bu yoğun Suriyeli nüfusu ile birlikte yaşama deneyimine, ülkemizin diğer şehirlerine oranla daha fazla sahip olmaları beklenmektedir. Bu noktadan hareketle, araştırma kapsamında katılımcılara, "Suriyeliler ile aynı şehirde birlikte yaşamaya alıştınız mı?" sorusu yöneltilmiş, katılımcıların verdikleri cevapların dağılımına Grafik 12' de yer verilmiştir. Bu soruya katılımcıların \%14,5'i evet, \%22,5'I kısmen, 8,3'ü kararsızım/fikrim yok, 54,7'si ise hayır cevabını vermiştir. Böylece, yerel halkın ikamet ettikleri şehirlerde yoğun bir Suriyeli nüfusu ile birlikte yaşamlarını sürdürmelerine rağmen bir arada yaşama alı̧̧ma noktasında farklı düzeylerde oldukları tespit edilmekte, soruya "hayır" cevabını verenlerin oranı $(\% 54,7)$ da göz önünde bulundurulduğunda ev sahibi toplum ve göç eden topluluk arasında tam bir toplumsal kabul ve uyumdan bahsetmek mümkün görünmemektedir. Katılımcıların anket formunun son sorusuna verdikleri cevapların dağılımı (Grafik 13) da bu tespiti doğrular niteliktedir.

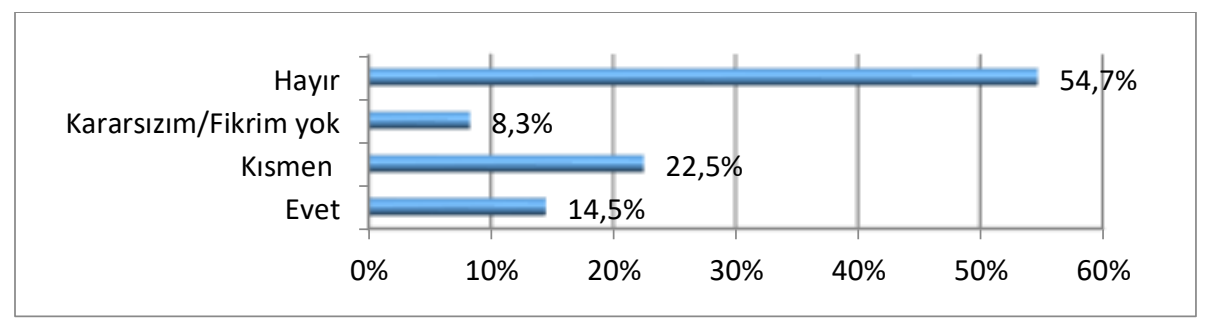

Grafik 13. "Türkiye'de yaşayan Suriyelileri ülkemizin bir parçası olarak görüyor musunuz?" sorusuna katılımcıların verdikleri cevapların dă̆ılımı 
Araştırma örneklemine yöneltilen"Türkiye'de yaşayan Suriyelileri ülkemizin bir parçası olarak görüyor musunuz?" sorusuna verilen cevaplar sirasiyla, \%54,7 hayır, \%22,5 kismen, \%14,5 evet ve $\% 8,3$ kararsızım/fikrim yok şeklindedir. Sınır kentlerde yaşayan halkın, savaşa bağlı kitlesel göç hareketiyle birlikte ülkemizde yaşamını sürdüren Suriyelilerin toplumsal kabul ve uyum sürecinde bir yol kat etmekle birlikte, bu yolun tamamlanması için zamana ihtiyaç duyduğu görülmektedir.

\section{Sonuç}

Göçün, temelde bir yerinden olma/edilme ile başlayan fiziksel yönü ile birlikte yerleşik kodların esastan sarsılmasına yol açan tüm psikolojik eşikleri birlikte değerlendirildiğinde, her göç deneyiminin yeni bir yaşam pratiği inşa etme konusunda oldukça sancılı bir sürece karşılık geldiği ifade edilebilir. Özellikle yaşanılan yere ait koşulların bütünüyle sarsıldığı, gündelik hayat pratiklerine ilişkin rutinlerin bozulduğu ve göçün zorunlu bir seçenek haline geldiği zorunlu göçmenlik deneyiminde zaman/mekân tasavvurunun kalıcı olarak altüst olması kişiler açısından daha yıkıcı ve onarımı zor bir yerinden edilme tecrübesi üretmektedir (Çakmak, 2018, s. 355). Üstelik göç ettikleri yerde yeni yaşamlarını dizayn etme süreçleri sadece göçmenler için değil aynı zamanda ev sahibi toplum için de sancılı geçmektedir. Bu sancılı toplumsal kabul ve uyum sürecine verilecek en güncel örnek ise, 2011 yllında başlayan Suriyeli göçü sonrasında Türkiye'de ve özellikle ülkenin sınır kentlerinde yaşanan gelişmelerdir.

Türkiye'ye yapılan Suriye kaynaklı zorunlu göç akımının başladığ günden itibaren bu hareketten en çok etkilenen şehirlerimiz şüphesiz Kilis, Gaziantep ve Hatay olmuştur. Suriyeliler ülkemize, bu şehirlerde bulunan sınır kapılarından giriş yapmışlar, bir kısmı direkt barınma merkezlerine yerleşmiş, bir kısmı bu üç ilin şehir merkezlerine kendilerine kalacak yer bulmuşlar, diğer kısmı ise bu şehirler üzerinden Türkiye'nin dört bir yanına dağılmışlardır. Üstelik bu süreç henüz sona ermemiş ve göç dalgasının onuncu yılında halen Suriye'den ülkemize girişler devam etmektedir. Bir başka ifadeyle, Suriye'den ülkemize gelen kişiler ya bu üç şehrimize yerleşmekte ya da bu şehirler üzerinden Tü- 
rkiye'ye dağılmaktadırlar. Hâl böyle olunca bu şehirlerde Suriyelilere yönelik toplumsal kabul ve uyum göstergeleri önem arz etmektedir.

Kilis, Gaziantep ve Hatay'da gerçekleştirilen saha araştırması sonucunda, yerel halk ve Suriyeliler arasında sosyal etkileşim ve iletişimin arttığ 1 tespit edilmektedir. Suriyelilerin bu şehirlerin farklı semtlerine dağıldıkları gözlenmekte, böylece komşuluk ilişkileri de kurulmaktadır. Suriyelilerin Türkçe öğrenme konusunda çabaları bulunmakla birlikte, bu şehirlerdeki Suriyeli yoğunluğu ve gündelik ihtiyaçlarını karşılamalarına olanak sağlayan market, manav, konfeksiyon gibi çeşitli işletmelerin sahiplerinin hemşehrileri olması, ayrıca hastane gibi kamu kurumlarında istihdam edilen tercümaların varlığı, gündelik yaşamda Türkçeye olan ihtiyacı bu bölgede büyük ölçüde azaltmaktadır. Suriyelilerin bir kısmının Türkçeye hakimiyetinin zayıflı̆̆ı, yerel halk ve Suriyeliler arasındaki iletişimi sekteye uğratmaktadır. İki grup arasındaki ekonomik ilişkiler incelendiğinde, araştırma örnekleminin yarısının, Suriyelilerin sınır kentlerde açmış oldukları dükkânlardan alışveriş yaptıkları tespit edilmiştir. Suriyelilerin ülkemizde istihdam edilmeleri ve ticari faaliyette bulunmaları konusunda ise diğer pek çok konuda olduğu gibi, yerel halktan destekleyenler olduğu gibi karşı çıkanlar da bulunmaktadır. Suriyelilerle arkadaşlık, komşuluk ve dostluk kuranlar bulunmakla birlikte, henüz hiç iletişime geçmeyenler de bulunmaktadır. Çocuklarının, Suriyeli çocuklarla aynı sıralarda eğitim görmelerinden ve arkadaş olmalarından rahatsız olmayacaklarını dile getiren yerli halktan önemli bir kitle bulunmakla birlikte, konu evliliğe ve yakın akrabalık ilişkileri kurmaya gelince yerli halkın negatif bir tavır sergilediği görülmektedir. Benzer bir durum mekânsal yakınlık konusunda da görülmektedir. Araştırma örnekleminin, Suriyelilerin şehrin belli mahallelerinde yerli halktan izole bir yaşam sürmelerinin doğru olmayacağını düşünmekle birlikte, aynı apartmanda yaşama konusunda olumsuz fikir beyan ettikleri ortaya çıkmaktadır. Suriyelilerin sınır kentlerde yaşama deneyimleri sonrasında bu şehirlerde birtakım değişikliklere sebep olmaları konusunda örneklemin neredeyse tamamı fikir birliği içerisinde olmakla birlikte, bu kişilerle bir arada yaşamaya henüz tam anlamıla uyum sağlamadıkları görülmektedir. Toplumsal kabul ve uyum sürecinin özellikle yerli halk açısından tamamlanmaması, Suriyelilerin ülkemizin bir parçası olduklarına dair bir algının büyük ölçüde 
oluşmadığını göstermektedir. Sonuç olarak, göç eden topluluk ve ev sahibi toplum arasında yoğun bir etkileşimin olmasının toplumsal kabul ve uyum sürecine katkısı olmakla birlikte, bu sürecin çift taraflı olduğu ve birlikte geçirilen huzurlu yıllara ihtiyaç duyulduğu görülmektedir. Böylece, toplumsal kabul ve uyumun söz konusu tarafların tümü için zor, sancilı ve zamana yayılan bir süreç olduğunu kabul etmek gerekmektedir. Ancak Türkiye'nin yerli halkının yüklendiği ve her geçen gün artan demografik yükün ağırlığ̣ göz önünde bulundurulduğunda, zamana yayılan bu sürecin zorluğu da anlaşılmaktadır. Bu sürecin daha hafif geçirilmesi noktasında ise, yerli halktan ziyade konuyla ilgili çalışmalar yürüten ve sürece etki edebilecek yetkili makamlara büyük iş düşmektedir. Her geçen gün nüfusları artan ve kalış süresi uzayan Suriyeli kitle ile ilgili siyasi yönetim, yerel yönetimler, ilgili kamu kurum ve kuruluşları, üniversiteler, sivil toplum kuruluşları, AFAD ve Kızılay gibi süreçte anahtar rol oynayan tüm birimlerin güncel ve daha kapsamlı çalışmalar yürütmesi gerekmektedir. Bu çalışmaların ayrıca bir koordine içerisinde yürütülmesi ve desteklenmesi gerekmektedir. Güvenlik, barınma, eğitim, sağlık, psiko-sosyal destek vb. konunun tüm boyutlarının etraflıca ele alınması ve her biriyle ilgili olarak gerekli planların, programların ve politikaların geliştirilmesi gerekmektedir. Geliştirilecek bu politikaların ise orta ve uzun vadede planlanması ve birbirleriyle ilişki içerisinde olmasına dikkat edilmesi gerekmektedir. Uzun vadeli politikaların oluşturulması ve uygulanabilmesi için ülkemizdeki Suriyeli kitleyle ilgili kapsamlı verilerin ilgili resmi birimler tarafından toplanması ve sürekli güncellenmesi gerekmektedir. Türkiye'deki yaşamını sürdüren Suriyeli nüfusun toplumsal kabul ve uyum süreciyle ilgili değerlendirilmesi gereken bir diğer nokta ise, Türkçe dil becerisi ve yeterliliğidir. Göçmen topluluğun, ev sahibi toplumla ve işleyen tüm sistemiyle bir uyumunun sağlanması için o topraklarda kullanılan resmi dili bilmesi büyük bir ön koşuldur. Türkiye' deki Suriyeli kitlenin Türkçe öğrenme konusunda heveslendirilmesi ve konuyla ilgili mevcut çalışmalara yenilerinin eklenmesi gerekmektedir. Örneğin ilk kademe eğitim hizmetlerine başlamadan önce Suriyeli çocukların, Türkçe dil kurslarından eğitim alması ve belirli bir seviyeye ulaştıktan sonra kursu tamamlaması sağlanabilir. Böylece küçük yaşlarda Türkçeyi öğrenmesi, eğitim hayatına daha sağlam adımlar başlaması ve başta okuldaki 
öğretmenler ve akranları olmak üzere Türk toplumuna daha kolay ve hızlı uyum sağlaması sağlanabilir. Yetişkin Suriyeliler için yerel bazda açılan Türkçe kurslarının sayısının arttırılması ve bu kurslara katılım konusunda yapılan teşviklerin ve desteklerin arttırılması gerekmektedir. Suriye' den Türkiye'ye geçişlerin halen devam etmesi ve Suriyeli ailelerin ülkemizde gözlerini dünyaya açan bebeklerinin sayısının her geçen artmasıyla birlikte Türkiye'deki Suriyeli nüfus artış göstermektedir. Türkiye'nin uyguladığı açık kapı politikası nedeniyle her geçen gün Suriye'den ülkemize yeni gelenlerin eklenmesini önlemek mümkün değildir. Bu durumda, Türkiye'de meydana gelen doğumlarla ilgili birtakım nüfus planlamaları yapılabilir. Örneğin sağlık kurumlarına başvuran Suriyeli kadınlara doğum kontrolüyle ilgili daha fazla bilgilendirme yapılabilir. Yapılan bu tür çalışmalara rağmen doğumların devam edeceği, Suriye'den Türkiye'ye geçişlerin sona ermediği, sürekli artan bu kitlenin gönüllü geriş dönüşlerinin de henüz mümkün olmadığı gerçeği birlikte düşünüldüğünde toplumsal kabul ve uyumun büyük önem taşıdığı görülmektedir. Türkiye'deki Suriyelilerin toplumsal kabul ve uyum konusu tüm ülke çapında önemli olmakla birlikte, özellikle Suriyeli nüfusun yoğun olduğu Kilis, Gaziantep, Hatay ve diğer güney sınır kentlerinde daha elzem ve acil olduğu yapılan bu araştırma sonucundan da anlaşılmaktadır. Bu uzun ve sancilı sürecin hem ev sahibi toplum hem de göç eden topluluk açısından bir nebzede olsa kolaylaşması adına benzeri güncel akademik çalışmalara ihtiyaç duyulmaktadır. 


\title{
EXTENDED ABSTRACT
}

\section{A Study on the Social Acceptance and Cohesion Processes of Syrians in Border Cities}

\author{
İpek Agcadağ Çelik \\ Kilis 7 Aralik University
}

The number of people who spend their entire lives in the settlement where they open and close their eyes to the world is decreasing worldwide. The main reason for this situation is the physical displacement of people for various reasons, in other words, the decision to live in a different village, city, country or even continent from where they were born. This decision may have been considered and made in the hopes of achieving better living conditions, or it may have been made involuntarily due to the helplessness caused by problems such as war, famine, climate change, although there was no desire to live in a place other than where one lived. Whatever the reason, the migration experience changes the lives of migrants economically, socially, culturally, psychologically and sometimes legally. Indeed, involuntary migration experience can have more shocking effects on people than voluntary migration experience. The experience of massively establishing a new order in a different settlement from their homeland affects not only the migrants but also the host society that welcomes them. When the international migration literature is examined, it is seen that the direction of this effect is generally negative for both migrants and host societies. Although it is seen that the basic needs such as security, shelter, employment, education and health are met in the new lands where the people who have involuntarily migrated have settled, the process of establishing a new life with the natives of these lands and making themselves accepted by the natives takes place in a longer period of time than expected. For the members of the host society, having to live with migrants who are different from some or all the elements such as language, race, religion, ethnic origin, sect, culture and lifestyle in their own land can be quite different and disturb- 
ing. This situation leads both sides to an uncomfortable process. How this process, which is called social acceptance and adaptation, will progress and how long it will last varies in each migration experience in individual and social dimensions. In cases where most of the factors listed above such as race, religion, language, ethnicity, sect, culture, and lifestyle are different between migrating and migration-receiving societies, it is inevitable that the process of social acceptance and adaptation will take longer. As the differences increase, the adaptation process of the migrants and the social acceptance process of the local people will be difficult and will spread over time. The prolongation of this process and the increase in its painfulness will lead to tension between the parties in social, cultural, economic, and psychological dimensions and to the deterioration of the atmosphere of peace. At this point, countries' migration management and crisis recovery skills/policies are of great importance. Political administrations will be responsible for developing and implementing policies that will moderate the social acceptance and adaptation processes of both sides. With the developed plans, programs, and practices, they will be able to mitigate this process and turn it in favor of the host society and migrants. Thus, the parties of the social acceptance and adaptation processes will be able to live together in a mutual tolerance, respecting each other's differences on the same land.

In recent years, Turkey has witnessed an example of the social acceptance process experienced during and after migration. Although the mass involuntary migration movement due to the Syrian war, which is the biggest humanitarian crisis in the world in recent years, has been on the world agenda since 2011, it is one of the most important problems that Turkey and the countries of the region where Syria is located are struggling to overcome. When the issue is approached specifically in Turkey, the lack of voluntary repatriation of Syrians, who were included in the scope of temporary protection status thanks to the successful crisis management, whose security was ensured and their basic needs were met quickly, brings new issues to the country's agenda. The social acceptance and adaptation processes occupy the agenda of Turkey and especially of the border cities that bear the demographic burden of the Syrian mass. Beyond just meeting basic human needs, it is possible to talk about the progress of social acceptance and adaptation processes 
with the actualization of incorporation of certain socio-cultural values of the host society without losing their own cultural values. For this reason, determining the current situation on the subject will both reveal the point reached today and shed light on the programs and policies to be prepared for the future. Considering that profound interaction turns into a disadvantage rather than an advantage in terms of social acceptance when a healthy communication and socio-cultural adaptation does not occur, the importance of field studies with local people is understood more. From this point of view, this research aims to reach the findings regarding the social acceptance and adaptation processes of the local people of Kilis, Gaziantep and Hatay, the border cities of Turkey, who are in a profound interaction with the Syrian mass in daily life.

As a result of the field research conducted in Kilis, Gaziantep and Hatay, it is determined that social interaction and communication between local people and Syrians have increased. It is observed that Syrians are dispersed to different districts of these cities, thus establishing neighborly relations. Although Syrians are making efforts to learn Turkish, the density of Syrians in these cities and the ownership of various businesses such as grocery stores, greengrocers and apparel that enable them to meet their daily needs, and the presence of translators employed in public institutions such as hospitals, greatly reduce the need for Turkish in daily life in this region. The weakness of some of the Syrians' command of Turkish interrupts the communication between the local people and the Syrians. When the economic relations between the two groups were examined, it was found that half of the research sample was shopping at shops opened by Syrians in border cities. As for the employment and commercial activities of Syrians in our country, as in many other issues, there are supporters from the local community as well as those who oppose it. While there are those who establish neighborliness and friendship with the Syrians, there are also those who have not yet communicated at all. Although there is a significant group of local people who stated that they would not be disturbed by their children being educated in the same classrooms and being friends with Syrian children, it is observed that they display a negative attitude when it comes to marriage and establishing close kinship relations. A similar situation can be observed in spatial proximity. Although the research sample thinks that 
it would not be right for Syrians to live in isolation from the locals in certain neighborhoods of the city, they expressed a negative opinion about living in the same building. Although almost all the research sample agree on the fact that Syrians caused some changes in these border cities after their experience of living in there, it is seen that they have not yet fully adapted to living together with them. The fact that the social acceptance and adaptation process is not completed, especially for the local people, shows that the perception that Syrians are a part of our country has not been formed to a large extent. In sum, although the profound interaction between the migrant community and the host society contributes to the social acceptance and adaptation process, it is seen that this process is two-sided and peaceful years spent together are needed. Thus, it is necessary to admit that social acceptance and adaptation is a difficult, painful, and time-consuming process for all parties involved. However, considering the weight of the gradually increasing demographic burden imposed by the local people of Turkey, the difficulty of this process that spreads over time is also understood. At the point of making this process lighter, a great deal of responsibility falls on the authorities, who carry out studies on the subject and can influence the process, rather than the local people. All units that play a key role in the process, such as the political administration, local administrations, relevant public institutions and organizations, universities, nongovernmental organizations, AFAD and Red Crescent, need to carry out up-to-date and more comprehensive studies regarding the Syrian population, whose population is increasing day by day and whose duration of stay is getting longer. These studies should also be carried out and supported in a coordinated manner. All aspects of the issue such as security, accommodation, education, health, psycho-social support, etc. should be dealt with in detail and necessary plans, programs, and policies should be developed for each. These policies to be developed should be planned in the medium to long term and attention should be paid to their relationship with each other. In order to formulate and implement long-term policies, comprehensive data on the Syrian population in our country should be collected by the relevant official units and updated continuously. Another point to be evaluated regarding the social acceptance and adaptation process of the Syrian population living in Turkey is Turkish 
language skills and proficiency. It is a great prerequisite for the migrant community to know the official language used in that land in order to ensure harmony with the host society and its entire functioning system. The Syrian population in Turkey should be encouraged to learn Turkish and new studies should be added to the existing studies on the subject. For example, it can be ensured that Syrian children receive education from Turkish language courses before starting primary education services and complete the course after reaching a certain level. Thus, it can be ensured that children learn Turkish at an early age, start their education life with more solid steps, and adapt more easily and quickly to Turkish society, especially their teachers and peers at school. It is necessary to increase the number of Turkish language courses offered locally for adult Syrians and to increase the incentives and supports for participation in these courses. The Syrian population in Turkey is increasing with the continuing transition from Syria to Turkey and with the increase in the number of babies of Syrian families who open their eyes to the world in our country. Due to the open-door policy implemented by Turkey, it is not possible to prevent the addition of new arrivals to our country from Syria every day. In this case, some population planning can be made regarding births that occur in Turkey. For example, Syrian women who apply to health institutions can be given more information about birth control. Considering the fact that births will continue despite such studies, the transition from Syria to Turkey will not end, and the voluntary repatriation of this ever-increasing mass is not yet possible, it is seen that social acceptance and adaptation are of great importance. Although the issue of social acceptance and adaptation of Syrians in Turkey is important throughout the country, it is understood from the results of this research that it is more essential and urgent especially in Kilis, Gaziantep, Hatay and other southern border cities where the Syrian population is dense. In order to facilitate this long and painful process for both the host society and the migrating community, similar current academic studies are needed. 


\section{Kaynakça / References}

Adıgüzel, Y. (2020). Göç sosyolojisi. Ankara: Nobel Akademik Yayıncılık.

Akıncı B., Nergiz, A., ve Gedik, E. (2015). Uyum süreci üzerine bir değerlendirme: göç ve toplumsal kabul, Göç Araştırmaları Dergisi, 1(2), 58-83.

Aktaş, E. ve Gülçür, İ. (2017). Suriyelilere yönelik toplumsal kabulü uyumu etkileyen sosyo ekonomik faktörler: Mersin ili Mezitli ilçesi örneği. Toplum ve Demokrasi, 11(23), 235-248.

Apak, H. (2014). Suriyeli göçmenlerin kente uyumları: Mardin örneği, Mukaddime Dergisi, 5(2), 53-70.

Budak, S. (2000). Psikoloji sözlü̆̆̈̈, Ankara: Bilim Sanat Yayınları.

Canbey Özgüler, V. (2018). Göç ve uyum politikaları. GSI Journals Serie B: Advancements in Business and Economics, 1(1). 1-10.

Çakırer Özservet, Y. (2019). Karşılaşma ve uyum bağlamında kent mekânı ve göçmenler. H. Sakız \& H. Apak (Der.), Türkiye'de göçmen kapsayıcılı̆̆ı sorundan firsata dönüşüm önerileri içinde (ss. 47-70). Ankara: Pegem Akademi Yayıncilik.

Çakmak, F. (2018). Zorunlu göç sürecinde mekânın kaybı ve evin yitimiyle başlayan yersiz yurtsuzluğun ürettiği bir travma olarak "kimliğin anonimleşmesi". Turkish Studies, 18(13), 349-364.

Çuhadar Gürkaynak, E. (2012), Toplumsal temas: Önyarg1 ve ayrımcılı̆̆ı önlemek için bir sosyal değişim aracı olarak kullanılabilir mi?. K. Çayır \& M. Ayan Ceyhan (Der.), Ayrımcılık: Çok boyutlu yaklaşımlar içinde (ss. 1-12). İstanbul: İstanbul Bilgi Üniversitesi Yayınları.

Deniz, O. (2009). Mülteci hareketleri açısından Van kentinin durumu ve kentteki mültecilerin demoğrafik profili. Doğu Coğrafya Dergisi, 14(22), 187-204.

Doğan, İ. (2012). Sosyolojik kavramlar ve sorunlar. Ankara: Pegem Akademi Yayincilik.

Erdoğan, M. M. (2020). Suriyeliler barometresi 2019 Suriyelilerle uyum içinde yaşamin çerçevesi. Ankara: Orion Yayın.

Eşim, İ. (2020). Balkanlardan Anadolu'ya yönelik göçlerïn mekânsal etkilerï (Bursa'daki Bulgaristan göçmenleri örneği). Yayınlanmamış yüksek lisans tezi. Bursa Uludağ Üniversitesi, Bursa.

Gönül, S. (2020). Zorunlu göç ve toplumsal cinsiyet: Suriyeli kadınların evlilik deneyimleri. K. Biehl \& D. Danış (Der.), Toplumsal cinsiyet perspektifinden Türkiye'de göç araştirmalari içinde (ss. 80-100). İstanbul: Sabanc1 Universitesi Toplumsal Cinsiyet ve Kadın C,alıssmaları Muikemmeliyet Merkezi. 
Gürbüz S. ve Şahin F. (2018). Sosyal bilimlerde araştırma yöntemleri: Felsefe, yöntem ve analiz. Ankara: Seçkin Yayıncilık.

Güven, S. (1996). Uluslararası işçi göçünün sosyal politika sorunları, Bursa: Uludağ Üniversitesi.

Orhan, O. ve Şenyücel, Gündoğar, Ş. (2015). Suriyeli sığınmacıların Türkiye'ye etkileri. Ankara: Ortadoğu Stratejik Araştırmalar Merkezi.

Sözer, M. A. (2019). Göç, toplumsal uyum ve aidiyet. Bayburt Eğitim Fakültesi Dergisi, 14(28), 418-431.

Süleymanov, A. (2017). Suriyelilerin Türk toplumunda toplumsal uyum ve sosyal kabul düzeyi, Türk Yurdu, 361, 27-30.

Tunç, A. Ş. (2015). Mülteci davranışı ve toplumsal etkileri: Türkiye'deki Suriyelilere ilişkin bir değerlendirme, TESAM Akademi, 2(2), 29-63.

Tümtaş, M. S. ve Ergun, C. (2016). Göçün toplumsal ve mekânsal yapi üzerindeki etkileri. Süleyman Demirel Üniversitesi İktisadi ve İdari Bilimler Fakültesi Dergisi, 21(4), 1347-1359.

Türkoğlu, O. (2011). Mülteciler ve ulusal/uluslararası güvenlik. Uludağ Üniversitesi İktisadi ve İdari Bilimler Fakültesi Dergisi, 30 (2), 101-118.

Türkyılmaz, A., Çay, A., Avşar, Z. B., Aksoy, M., Pehlivanlı, H. ve Kökrek, Z. (1998). Doğu ve Güneydoğu Anadolu'dan terör nedeniyle göç eden ailelerin sorunları, Ankara: Başbakanlık Aile Araştırma Kurumu.

Yardım, M. (2017). Göç ve entegrasyon politikaları ışı̆̆ında Fransa'da toplumsal Kabul. Göç Araştırmaları Dergisi, 3(2), 100-136.

Yavuz, S. (2013). Göç, entegrasyon ve din: Avrupa'da yaşayan Türkler bağlaminda bir değerlendirme. Uluslararası Sosyal Araştırmalar Dergisi, 6 (26), 610-623.

\section{Kaynakça Bilgisi / Citation Information}

Ağcadağ-Çelik, İ. (2021). Suriyelilerin sınır kentlerdeki toplumsal kabul ve uyum sürecine ilişkin bir araştırma. OPUS-Uluslararası Toplum Araştırmaları Dergisi, 17(37), 4784-4823. DOI:10.26466/opus.899920 